Editor:

Umi Muzayanah \& Wahab

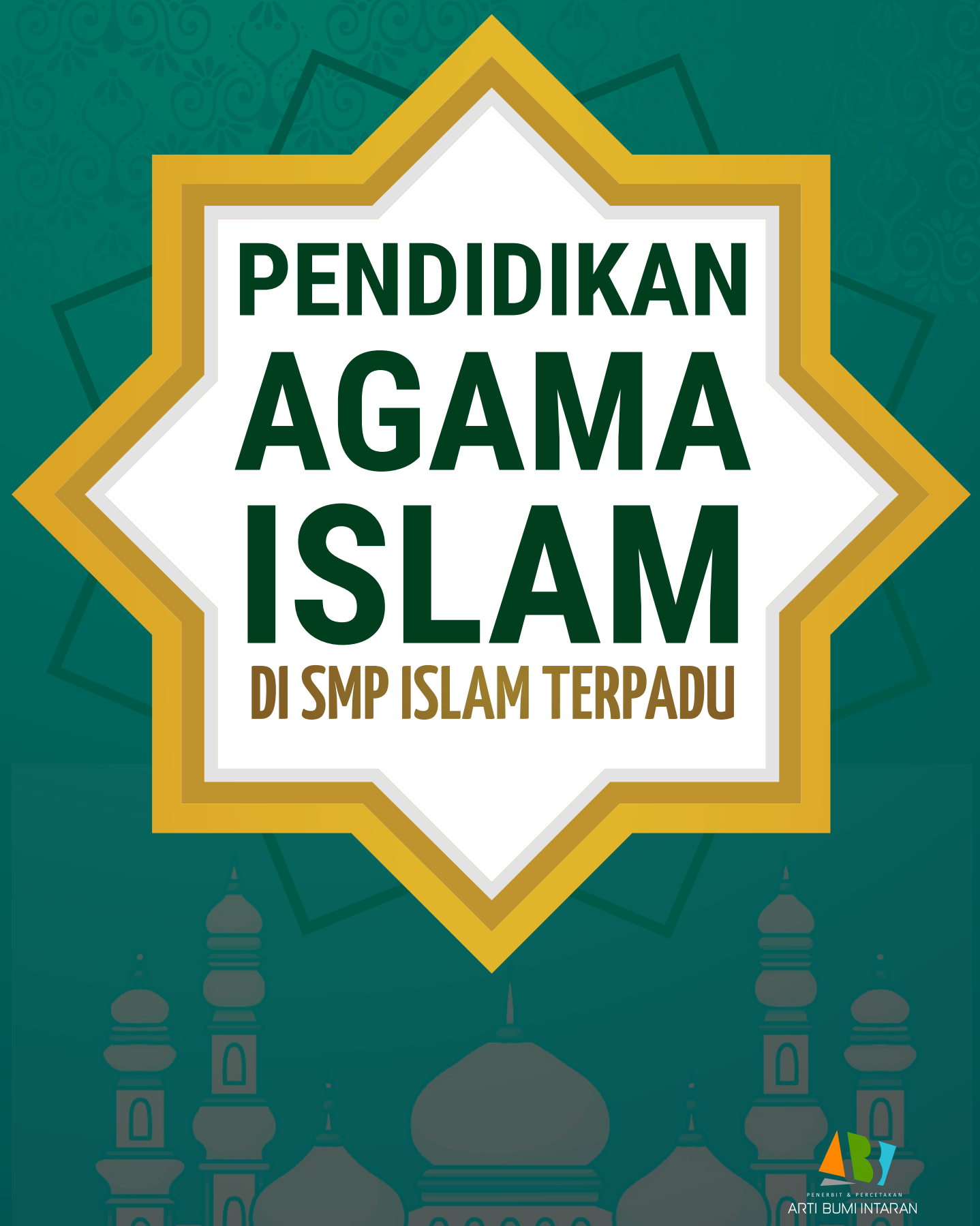




\section{PENDIDIKAN AGAMA ISLAM DI SMP ISLAM TERPADU}

Editor: Umi Muzayanah dan Wahab

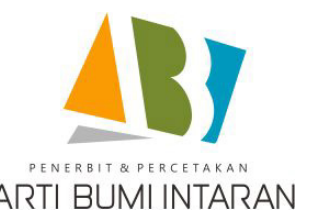




\section{PENDIDIKAN AGAMA ISLAM DI SMP ISLAM TERPADU}

Penulis: Wahab, dkk.

Editor: Umi Muzayanah dan Wahab

Layout dan Desain Cover: Ibnu Abdillah dan Ahmad Bahauddin

Cetakan Pertama, Desember 2019

16 x $24 \mathrm{~cm}$, xiv $+343 \mathrm{hlm}$.

ISBN: 978-602-5963-71-1

Penerbit:

CV. Arti Bumi Intaran

Mangkuyudan MJ III/216 - Yogyakarta

Telp./Facs.: (0274) 380228

Email: artibumiintaran@gmaill.com

Website: www.artibumiintaran.com

Anggota IKAPI

\section{Bekerjasama dengan}

Balai Penelitian dan Pengembangan Agama Semarang

J1. Untung Suropati Kav. 70, Bambankerep - Ngaliyan - Semarang, 50211 Telp. (024) 7601327, Facs. (024) 7611386

Email: bla_semarang@kemenag.go.id

Website: www.blasemarang.kemenag.go.id

Perpustakaan Nasional: Katalog Dalam Terbitan (KDT)

Hak cipta dilindungi undang-undang

Isi di luar tanggungjawab percetakan 


\section{PENGANTAR EDITOR}

Pendidikan Agama Islam (PAI) adalah salah satu mata pelajaran wajib dalam struktur kurikulum nasional di setiap jenjang pendidikan. Selain Pendidikan Kewarganegaraan (PKn), mata pelajaran PAI merupakan subjek yang sarat dengan pesan moral, baik moral yang bersifat vertikal (religiusitas) maupun pesan moral yang bersifat horisontal (sikap sosial). Oleh karena itu, PAI menempati posisi yang strategis dalam mewujdukan tujuan pendidikann nasional, yang salah satunya adalah membentuk manusia yang beriman dan bertakwa kepada Tuhan Yang Maha Esa dan berakhlak mulia.

Dalam tataran praktis, pelaksanaan PAI di lembaga pendidikan jenjang dasar dan menengah mengalami pergeseran yang cukup siginifikan. Salah satunya ditandai dengan bertambahnya alokasi jam pelajaran (JP), yang semula hanya 2 JP per minggu menjadi 3 JP per minggu. Penambahanan jumlah JP memberikan peluang kepada guru dan siswa untuk berinteraksi lebih lama dalam pembelajaran PAI, baik yang bersifat teoretis maupun praktik. Selain itu, penambahan jumlah JP juga memberikan kesempatan kepada guru untuk berelaborasi dan melakukan diversifikasi metode pembelajaran dalam rangka pencapaian tujuan pembelajaran yang lebih optimal.

Pentingnya peran PAI dalam penyelenggaraan pendidikan di sekolah menjadi spirit para penyelenggara pendidikan untuk melakukan inovasi yang lebih menarik 
minat masyarakat, khususnya inovasi yang relevan dengan tujuan diselenggarakannya Pendidikan Agama Islam. Apalagi, perkembangan pada era revolusi industri 4.0 yang ditandai dengan perkembangan teknologi yang super canggih membawa dampak yang sangat siginifikan terhadap kehidupan manusia. Hadirnya beragam gadget sedikit banyak membawa perubahan pada pola interaksi sosial masyarakat, tidak hanya pada kalangan masyarakat dewasa, namun juga pada kalangan anak-anak. Kemudahan akses internet yang nyaris tanpa filter memberikan efek "ketagihan" bagi warganet yang kini merambah luas ke dunia anak-anak.

Terjadinya disruptif teknologi di atas banyak membawa dampak negatif bagi anak-anak generasi milenial, yang berujung pada kecemasan orang tua terhadap pergaulan anak-anaknya. Maraknya kenakalan remaja dan pergaulan bebas di kalangan remaja menjadi warning bagi para orang tua atas dekadensi moral yang dapat mengancam anak-anak mereka. Inilah yang mendasari terjadinya parental choice of education yang semakin tampak pada beberapa dekade terakhir. Masyarakat pada saat ini memiliki kecenderungan untuk tidak lagi menjadikan sekolah umum pertama bagi anak-anaknya, namun banyak orang tua yang kini memilih pesantren, madrasah, atau sekolah yang menyematkan "Islam" dan "Islam Terpadu" sebagai branded sekolah mereka. Hal ini disadari merupakan peluang bagi sekolah swasta Islam untuk memberikan tawaran terbaiknya berupa kurikulum yang memberikan nilai lebih pada muatan nilai- 
nilai Islam dibanding sekolah umum. Di antara sekolah yang saat ini bergeliat maju dan berkembang adalah sekolah dengan branded Islam Terpadu (IT).

Sekolah Islam Terpadu (SIT) saat ini tumbuh subur di Indonesia. Sekolah Islam Terpadu dimaknai sebagai sekolah yang menerapkan pendekatan penyelenggaraan dengan memadukan pendidikan umum dan pendidikan agama menjadi satu jalinan kurikulum. Sistem pembelajaran pada SIT secara umum menerapkan fullday school, namun tidak sedikit pula sekolah IT yang menerapkan sistem pembelajaran boarding school. Keberadannya seolah menjadi jawaban atas kegelisahan masyarakat akan ancaman dekadensi moral yang sewaktu-waktu dapat membahayakan anak-anak mereka. Masyarakat, khususnya yang berada di kelas sosial menengah ke atas cenderung menggantungkan masa depan anak mereka kepada SIT, mulai dari jenjang SD, SMP, hingga SMA. Beberapa hal yang menjadi daya tarik sekolah IT adalah adanya muatan nilai-nilai Islam yang lebih kental dibanding sekolah umum sehingga mampu mengimbangi kebutuhan siswa atas pendidikan agama Islam yang hanya diberikan sebanyak 3 JP per minggu. Bahkan, salah satu karakteristik sekolah IT adalah melakukan internalisasi nilai-nilai Islam di dalam mata pelajaran umum, seperti Matematika, IPA, IPS, dan lainnya.

Lantas bagaimana sesungguhnya implementasi PAI di sekolah IT dan bagaimana "keterpaduan" yang menjadi ciri khas SIT?. Buku Pendidikan Agama Islam di SMP Islam

Terpadu ini berisi kumpulan artikel yang berangkat dari 
penelitian "Implementasi Pendidikan Agama Islam (PAI) di SMPIT di Jawa Tengah, Jawa Timur, dan D.I. Yogyakarta”. Deskripsi tentang pelaksanaan PAI di sekolah Islam Terpadu tergambarkan dalam buku ini, yang dibatasi pada kajian PAI di jenjang SMPIT. Buku ini terdiri dari sebelas tulisan, yang ditulis oleh peneliti Balai Litbang Agama Semarang.

Tulisan pertama merupakan karya dari Wahab, yang merupakan prolog dari buku bunga rampai ini. Melalui tulisan yang dibuatnya, Wahab berupaya memayungi tulisan-tulisan selanjutnya dengan kerangka konsep, metodologi, dan alat analisis yang mendekati seragam. Wahab juga menyajikan gambaran secara umum bagaimana pelaksanaan PAI, bagaimana keterpaduan kurikulum yang dikembangkan, dan varian kegiatan ekstrakurikuler yang relevan dengan PAI pada SMPIT yang menjadi lokus penelitian di Jawa Tengah, Jawa Timur, dan D.I. Yogykarta.

Umi Muzayanah menyoroti bagaimana antusiasme masyarakat dalam menyekolahkan anak-anak mereka ke SMPIT, sebagai bagian dari adanya parental choice of education. Di Surabaya, Umi menyebutkan setidaknya ada empat SMPIT yang sudah cukup "mapan" ditinjau dari eksistensinya. Namun demikian, SMPIT Al-Uswah dipilih sebagai objek kajian mengingat lokasi yang berada di tengah kota dan memiliki siswa yang cukup banyak. SMPIT A1Uswah yang berada di bawah naungan Jaringan Sekolah Islam Terpadu (JSIT) ini mengacu pada kurikulum Dinas Pendidikan yang dipadukan dengan kurikulum khas JSIT. Pengembangan afeksi siswa di SMPIT Al-Uswah sebagian besar telah dilakukan melalui pengembangan kurikulum 
Islam terpadu. SMPIT Al-Uswah juga mengembangkan kurikulum pendidikan agama Islam (PAI) dengan menambah muatan Alquran Hadis dan Bahasa Arab.

Masih di wilayah Jawa Timur, pelaksanaan PAI di SMPIT Bina Insan Cendekia (BIC) yang terletak di Kota Pasuran yang juga berada di bawah naungan JSIT menerapkan PAI sesuai dengan kurikulum kedinasan. Artikel yang ditulis oleh Siti Muawanah menyebutkan bahwa implementasi PAI di SMPIT BIC ditunjang pula oleh kegiatan pembiasaan yang sarat dengan nilai-nilai Islam. Selain itu, beberapa kegiatan ekstrakurikuler seperti Seni Kaligrafi dan Seni Qiroatul Qur'an turut mendukung pelaksanaan PAI, meski bukan dukungan secara langsung.

A.M. Wibowo mengaitkan implementasi PAI di SMPIT Izzatul Islam Kabupaten Semarang Jawa Tengah dengan tantangan era disruptif, yang pada akhirnya melahirkan tantangan bagi pendidikan agama Islam. SMPIT Izzatul Islam mempersiapkan dan membekali siswanya melalui penguatan PAI, tidak hanya pada tataran intrakurikuler, melainkan juga melalui budaya sekolah yang Islami dan kegiatan ekstrakurikuler. Selain itu, pelaksanaan PAI juga dikuatkan dengan sistem pembelajaran boarding school yang diselenggarakan di SMPIT Izzatul Islam. Sesuai dengan visi sekolah, implementasi dan internalisasi pendidikan agama Islam dilakukan dalam rangka membentuk karakter Sholih, Ilmuwan, Pemimpin Kreatif dan Smart (SIPKS). Hal ini dilakukan sebagai upaya membekali siswa untuk menghadapi era disruptif. 
Tulisan selanjutnya mendeskripsikan pelaksanaan PAI di SMPIT Ihsanul Fikri Kabupaten Magelang Jawa Tengah. Sebagaimana pada Sekolah-sekolah IT sebelumnya, melalui tulsiannya, Nugroho Eko Atmanto memaparkan bahwa SMPIT Ihsanul Fikri menerapkan "keterpaduan" antara pendidikan umum dan keagamaan. Keterpaduan dapat dijumpai pada pembelajaran dari aspek pengetahuan umum dan aspek karakter keagamaan, baik pembelajaran formal di sekolah maupun di asrama. Pembelajaran di sekolah dengan memadukan kurikulum nasional (43 jam) dan kurikulum lokal (14 jam). Keberadaan pendidikan di SMPIT Ihsanul Fikri tidak terlepas dari dukungan orang tua siswa dan masyarakat sekitar, serta dukungan yayasan.

Pelaksanaan PAI di SMPIT Ar-Raihan Bantul dan SMPIT Masjid Syuhada Kota Yogyakarta dipaparkan melalui tulisan yang ditulis oleh Wahab. Pelaksanaan pembelajaran PAI di kedua sekolah IT ini secara umum sama dengan SMPIT lainnya, yaitu sebagian menggunakan Kurikulum 2013 dan sebagian lainnya menggunakan Kurikulum 2006. Selain kedua kurikulum tersebut, implementasi PAI di sekolah ini juga mengacu pada kurikulum khas yayasan/ sekolah dan kurikulum JSIT. Upaya memperkuat akhlak dan perilaku keagamaan siswa dilakukan melalui kegiatankegiatan pembiasaan sebagai upaya pengembangan dan penguatan ranah afektif dan psikomotorik siswa terkait dengan karakter dan perilaku keagamaan Islam.

Tulisan berikutnya ditulis oleh Ahmad Muntakhib, yang memaparkan bagaimana pelaksanaan PAI di SMPIT Az-Zahra Demak. Ia banyak memberikan deskripsi terkait 
dengan budaya sekolah yang berkaitan erat dengan nilainilai Pendidikan Agama Islam. Budaya sekolah yang Islami termanifestasi dari tata tertib berupa kewajiban dan larangan siswa selama berada di lingkungan sekolah. Berbagai upaya telah dilakukan SMPIT Az-Zahra agar PAI dapat dilaksanakan secara maksimal. Di antaranya adalah dengan menerapkan sistem pembelajaran boarding school, memberikan perhatian khusus bagi siswa yang berpuasa, sentuhan rohani setiap habis salat berjamaah, dan tata tertib.

Dandung Budi Yuwono melalui tulisannya mendeksirpsikan pelaksanaan PAI di SMPIT Al-Ikhlas Mantren Magetan. Dandung menyebutkan bahwa implementasi setiap mata pelajaran di SMPIT Al-Ikhlas Matren yaitu dengan cara memadukan antara komponen jasad, hati, dan otak yang disinergiskan dengan pemahaman Asmaul Husna. Evaluasi pengembangan kurikulum terus dilakukan dalam rangka melakukan penyesuaian terhadap kebutuhan kontekstual. Untuk itu, Yayasan Al-Ikhlas memiliki Biro Kelitbangan yang bertugas untuk melakukan evaluasi terhadap pengembangan kurikulum sebagai acuan untuk pengembangan pada tahun selanjutnya.

Tulisan selanjutnya berangkat dari peneltiian yang dilakukan di SMPIT Qurrota A'yun Kabupaten Ponorogo, yang ditulis oleh Muh. Isnanto. Ia menyoroti tentang aspek keterpaduan kurikulum yang dilakukan oleh SMPIT Qurrota A'yun. Implementasi PAI di sekolah ini menggunakan kurikulum Diknas, namun SMPIT ini juga memberikan pelajaran Hadis, Fikih, dan Akidah Akhlak 
layaknya kurikulum Kementerian Agama. Hal menarik juga diselenggarakan oleh SMPIT Qurrota A'yun yaitu program every day with Alquran (tilawah dan tahfizh), pembinaan ibadah harian, pembinaan "mentoring" pekanan, pekan pahasa Arab dan English, mabit (Malam Bina Iman dan Taqwa).

Aji Sofanudin dan Mukhtarudin menulis tentang implementasi PAI di SMIT Insan Kamil Karanganyar. Sebagaimana beberapa SMPIT lainnya, sekolah yang dibahas dalam tulisan mereka juga tergabung dalam JSIT Indonesia. Impelemntasi PAI di SMPIT Insan Kamil Karanganyar mengacu pada model JSIT, dengan penambahan beberapa mata pelajaran yang mendukung PAI, yaitu Bahasa Arab, Tahfizh, dan Ke-IT-an. Sistem pembelajaran yang diselenggarakan oleh sekolah ini adalah fullday school dan boarding school. Selain itu, kegiatan pembiasaan diri juga sudah tampak sebagai representasi dari PAI pada tataran praktis, yaitu salat berjamaah, salat duha, puasa Senin Kamis, pengajian kitab kuning, tahsin dan tahfizh, serta bina pribadi Islam (BPI).

Zakiyah menulis epilog sebagai pungkasan dari isi buku ini. Ia banyak mengkaji SIT dalam diskursus penelitian terdahulu, termasuk penelitian-penelitian yang ditulis dalam buku ini. Zakiyah juga menambahkan bahwa keberadaan SIT merupakan fenomena penyediaan pendidikan yang difasilitasi masyarakat dan banyak diminati oleh orang tua siswa untuk menyekolahkan anak mereka di lembaga ini. Fenomena ini terbukti dg terus meningkatnya jumlah sekolah dengan model Islam Terpadu. 
Kumpulan tulisan di atas memberikan gambaran bagaimana praktik pelaksanaan PAI di SMPIT yang memiliki ciri khas pada pengembangan kurikulum terpadu. Kajian tersebut penting dalam menambah wawasan terkait warna dan inovasi pendidikan, khususnya yang berkaitan dengan Pendidikan Agama Islam. Pengembangan afeksi yang dilakukan melalui kegiatan pembiasaan diri, budaya sekolah Islami, tahfizh, kontrol ibadah harian di rumah, turut menjadi program unggulan SMPIT yang menjadi daya tarik tersendiri yang tidak diberikan oleh sekolah umum. Hal ini tentu menjadi menarik apabila program-program pengembangan afeksi dapat diadopsi di sekolah umum, yang tentu disesuaikan dengan kebutuhan dan kondisi setempat. Dengan demikian, Pendidikan Agama Islam tidak hanya diberikan guru dan diterima siswa terbatas pada tataran kognitif saja, melainkan dapat menjadi pembiasaan yang dapat membentuk karakter religius dan sikap sosial siswa, tidak hanya di sekolah, melainkan juga di keluarga dan masyarakat.

Penerbitan buku ini tidak terlepas dari konstribusi beberapa pihak, baik langsung maupun tidak langsung. Ucapan terima kasih kami sampaikan kepada Kepala Balai Penelitian dan Pengembangan Agama Semarang yang telah memberikan dukungan penuh terhadap proses penerbitan, dari persiapan hingga pencetakan buku. Ucapan terima kasih juga kami sampaikan kepada seluruh pengelola SMPIT beserta yayasan yang menaunginya, yang telah dengan terbuka menerima para peneliti untuk melakukan penggalian data terkait dengan pelaksanaan PAI dan inovasi 
yang dikembangkan. Kami juga mengucapkan terima kasih kepada JSIT selaku pusat penggerak dan pemberdaya Sekolah Islam Terpadu di Indonesia yang telah memberikan ijin kepada SMPIT yang berada pada naungan JSIT sehingga proses penelitian berjalan dengan lancar. Secara khusus, terima kasih kami sampaikan kepada para penulis yang telah memberikan kontribusi tulisannya sehingga dapat menjadi referensi ilmiah bagi pemerhati dunia pendidikan.

Tidak dipungkiri bahwa masih banyak kelemahan, kekurangan, dan keterbatasan yang dijumpai pada buku ini, yang diakibatkan karena keterbatasan yang kami miliki. Oleh karena itu, saran, kritik, dan masukan kami harapkan dari pembaca sebagai bahan evaluasi sekaligus sebagai modal berharga untuk penerbitan buku pada waktu yang akan datang.

Selamat membaca.

Editor

Umi Muzayanah dan Wahab 
Pengantar Editor.......................................................ii

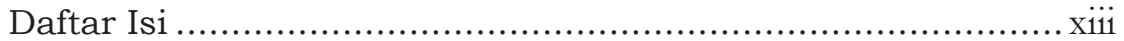

PROLOG:

IMPLEMENTASI PENDIDIKAN AGAMA ISLAM PADA SEKOLAH MENENGAH PERTAMA ISLAM TERPADU (SMP IT)

Wahab 1

PENGEMBANGAN AFEKSI SISWA MELALUI KURIKULUM ISLAM TERPADU PADA SMPIT AL-USWAH SURABAYA

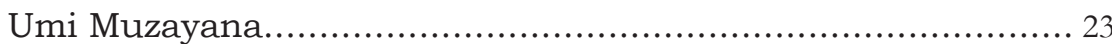

IMPLEMENTASI PENDIDIKAN AGAMA ISLAM DI SEKOLAH ISLAM TERPADU BINA INSAN CENDEKIA PASURUAN

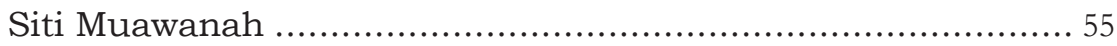

PENDIDIKAN AGAMA ISLAM PADA ERA DISRUPTIF DI SEKOLAH BERJEJARING SEKOLAH ISLAM TERPADU

A.M. Wibowo 81

IMPLEMENTASI PENDIDIKAN AGAMA ISLAM PADA SMPIT IHSANUL FIKRI PABELAN KABUPATEN MAGELANG

Nugroho Eko Atmanto

IMPLEMENTASI PENDIDIKAN AGAMA ISLAM PADA SMPIT AR RAIHAN BANTUL DAN SMPIT MASJID SYUHADA KOTA YOGYAKARTA

Wahab 
IMPLEMENTASI PENDIDIKAN AGAMA ISLAM PADA SEKOLAH MENENGAH PERTAMA ISLAM TERPADU BOARDING SCHOOL AZ-ZAHRA DEMAK

Ahmad Muntakhib

IMPLEMENTASI EKSTRAKURIKULER BERBASIS PESANTREN: KEKHASAN PADA SMPIT AL-IKHLAS MANTREN MAGETAN

Dandung Budi Yuwono

MENEROPONG DINAMIKA IMPLEMENTASI PENDIDIKAN AGAMA ISLAM DI SMPIT QURROTA A'YUN PONOROGO JAWA TIMUR

Muh. Isnanto

KARAKTERISTIK KURIKULUM PADA SEKOLAH DI BAWAH JARINGAN SEKOLAH

ISLAM TERPADU (JSIT) : Studi pada SMPIT Insan Kamil Karanganyar

Aji Sofanudin dan Mukhtarudin

EPILOG: PENDIDIKAN AGAMA ISLAM DI SEKOLAH ISLAM TERPADU DAN KEGAIRAHAN DALAM BERAGAMA

Zakiyah

BIBLIOGRAFI

BIODATA PENULIS 


\title{
PENDIDIKAN AGAMA ISLAM PADA ERA DISRUPTIF DI SEKOLAH BERJEJARING SEKOLAH ISLAM TERPADU
}

\author{
A.M. Wibowo
}

\section{Pendahuluan}

Saat ini dunia memasuki era disruptif, yang ditandai dengan terjadinya perubahan besar-besaran pada kehidupan manusia secara cepat akibat pengaruh globalisasi. Globalisasi tidak dengan sendirinya membawa nilai-nilai kemanusiaan, tetapi globalisasi juga ikut memelihara dan mengembangkan nilai-nilai lokal suatu masyarakat atau bangsa (Tilaar, 2005: 28). Globalisasi berdampak pada perubahan semua kegiatan manusia dari yang bersifat manual (mekanik) ke arah digital, dari yang bersifat nyata beralih pada dunia maya.

Globalisasi tidak selamanya bermakna positif. Terkadang ia membawa dampak negatif karena memudarkan nilai-nilai lokal pada suatu tempat akibat gaya hidup budaya luar yang diadopsi ke dalam kehidupan masyarakat tertentu. Globalisasi terkadang bertentangan dengan kenyataan hidup di dalam lingkungan masyarakat, kebudayaan lokal dan kehidupan beragama. Masyarakat perlu dibekali dengan penanaman nilai-nilai agama dan nilai-nilai lokal yang kuat untuk memproteksi pengaruh negatif globalisasi. Salah satu bentuk proteksi pengaruh negatif globalisasi adalah dengan pendidikan agama yang kuat.

Globalisasi di bidang teknologi berdampak pada perubahan cara berfikir manusia dari yang bersifat mekanik kepada yang bersifat artificial intelegence atau kecerdasan 


\section{Pendidikan Agama Islam Pada Era Disruptif di Sekolah Berjejaring Sekolah Islam Terpadu}

buatan. Bahkan, saat ini ketergantungan manusia kepada kecerdasan buatan ini terlihat semakin kuat, khusunya pada hal-hal yang bersifat pengayaan informasi dan komunikasi. Era ketergantungan kepada hal-hal yang bersifat artificial intelegence ini menurut penulis masuk pada era industri 4.0 atau lebih dikenal dengan era disrupsi.

Disrupsi (disruption) istilah yang dipopulerkan oleh Christensen, C (1997)sebagai kelanjutan dari tradisi berpikir "harus berkompetisi, untuk bisa menang (for you to win, you've got to make somebody lose)". Pemikiran Profesor Harvard Business School selama 22-37 tahun terakhir ini telah mendominasi dunai bisnis. Perubahan besarabesaran pada era disruptif atau lebih dikenal dengan era revolusi industri 4.0 merupakan tantangan bagi pendidikan seperti halnya pendidikan agama Islam. Era disruptif tidak harus dihindari tetapi harus dihadapi dengan bijak oleh pendidikan Islam karena hal tersebut tidak mungkin terelakkan. Pendidikan Agama Islam juga harus mampu mengikuti perubahan zaman.

Pendidikan Agama Islam merupakan proses mengubah tingkah laku individu peserta didik pada kehidupan pribadi, masyarakat dan alam sekitarnya. Proses tersebut dilakukan dengan cara pendidikan dan pengajaran sebagai sesuatu aktivitas asasi dan profesi di antara sekian banyak profesi asasi dalam masyarakat (Assyibani dalam Tafsir (2005: 45) .D. Mariamba (1989) mengemukakan bahwa pendidikan Islam adalah bimbingan atau pimpinan secara sadar oleh pendidik terhadap perkembangan jasmani dan rohani peserta didik menuju terbentuknya kepribadian yang utama (insan kamil). 
Muhaimin dalam Khuzaimah (2017) mengungkapkan bahwa pengembangan Pendidikan Agama Islam di sekolah sangat bervariasi, mencakup horizontal-lateral yakni bidang studi (non-agama) dan vertical-linier yaitu mendudukan agama sebagai sumber nilai atau sumber konsultasi dari berbagai studi. Pada umumnya yang dikembangkan pada satuan Pendidikan adalah pola horizontal-lateral terkecuali satuan pendidikan tertentu yang memiliki komitmen, kebijakan politik dalam mewujudkan relasi/hubungan keduanya.

Pada era pendidikan Islam konvensional, figur guru agama merupakan pusat dari pembelajaran. Guru merupakan sumber pengetahuan utama di dalam kelas. Dalam konteks pendidikan Islam modern hal tersebut mengalami pergeseran peran. Guru tidak lagi menjadi tokoh sentral sebagai satu-satunya sumber pengetahuan, namun hanya sebagai fasilitator pembelajaran. Hal ini disebabkan siswa pada era modern dapat mudah memperoleh informasi tentang agama Islam dari mana saja, seperti buku, media sosial, dan internet. Dalam pendidikan Islam modern terjadi pergeseran dari teacher centered menjadi student centered.

Fungsi guru agama pada era disruptif berbeda dibandingkan guru masa lalu. Saat ini guru agama tidak mungkin mampu bersaing dengan mesin dalam hal melaksanakan pekerjaan hafalan, hitungan, hingga pencarian sumber informasi. Mesin jauh lebih cerdas, berpengetahuan, dan efektif dibandingkan kita karena tidak pernah lelah melaksanakan tugas. Karena itu fungsi guru agama harus bergeser dari yang tadinya sebagai sumber informasi -bahkan satu-satunya sumber belajar- bergeser 


\section{Pendidikan Agama Islam Pada Era Disruptif di Sekolah Berjejaring Sekolah Islam Terpadu}

lebih pada mengajarkan nilai-nilai etika, budaya, karakter, kebijaksanaan, pengalaman hingga empati sosial karena nilai-nilai itu yang tidak dapat diajarkan oleh mesin.

Berbicara tentang era disruptif dan tantangannya dalam dunia pendidikan merupakan hal yang sangat menarik khususnya dalam dunia Pendidikan Agama Islam. Pendidikan Agama Islam memiliki peran utama dalam mendidik, membina peserta didik beragama Islam sebagai transfer of knowledge dan transfer of value ajaran agama Islam tidak hanya sebatas how to know dan how to do saja melainkan how to be menjadi muslim secara total kelak di kemudian hari.

Pendidikan Agama Islam merupakan salah satu mata pelajaran wajib yang diajarkan di satuan pendidikan, termasuk pada sekolah yang berjejaring dengan jaringan Sekolah Islam Terpadu (SIT). Salah satu tujuan pendidikan agama di SIT adalah melakukan transfer or knowledge dan value agar peserta didik mampu menjadi muslim yang menjalankan ajaran Islam, baik di dalam sekolah maupun kelak ketika mereka lulus dari satuan pendidikan.

Tulisan ini merupakan sebuah kajian tentang implementasi dan internalisasi nilai-nilai Pendidikan Agama Islam pada sekolah berjejaring dengan Jaringan Sekolah Islam Terpadu (JSIT) di dalam menghadapi era disruptif. Implementasi dan internalisasi pendidikan agama Islam ini meliputi implementasi kurikulum Pendidikan Agama Islam dan internalisasi nilai-nilai pendidikan agama Islam, baik di dalam pembelajaran maupun di luar pembelajaran, baik di sekolah maupun di asrama (boarding school). 


\section{Kajian Pustaka dan Kajian Teori}

\section{Kajian Pustaka}

Priatmoko (2018) mengungkapkan bahwa era disruptif membawa dampak pada semua lini kehidupan manusia, termasuk di dalamnya adalah dunia pendidikan Islam. Di era disruptif ini, pendidikan Islam perlu turut mendisruptifkan diri dengan cara melakukan pembaruan dan inovasi terhadap sistem, tata kelola, kurikulum, kompetensi sumber daya manusia, sarana dan prasarana, budaya, etos kerja, dan lain-lain. Karena jika tidak maka pendidikan Islam akan semakin tertinggal dan usang.

Persoalan pendidikan agama di era diruptif tidak hanya bagaimana mengganti kelas pembelajaran secara konvensional saja, tetapi yang lebih penting adalah bagaimana menyiapkan para pendidik sebagai sumber belajar, mentor sekaligus fasilitator bahkan motivator dan inspirator dalam mengembangkan imajinasi, kreativitas, karakter yang dibutuhkan pada masa depan. Selain itu adalah bagaimana peran sekolah, dan guru agama meminimalisir dampak negatif dari era distruptif itu sendiri yaitu melakukan penyaringan terhadap informasi yang ada di dunia maya yang mungkin dasar keilmuan atau sanad keilmuannya ternyata tidak berdasar pada kaidah agama yang sebenarnya, seperti hoax, fitnah, berita bohong, informasi yang tidak benar serta lain sebaginya.

\section{Era Disruptif dan Tantangan Pendidikan Agama}

Era disruptif merupakan turunan dari era milenial, dimana era ini terjadi perubahan besar-besaran terhadap semua lini kehidupan dan perilaku manusia. Era ini ditandai 


\section{Pendidikan Agama Islam Pada Era Disruptif di Sekolah Berjejaring Sekolah Islam Terpadu}

dengan adanya sikap dan perilaku manusia yang cenderung suka dengan kebebasan, senang melakukan personalisasi, mengandalkan kecepatan informasi yang instan (siap saji), suka belajar, bermain game dan bekerja dengan lingkungan yang inovatif. Selain itu, perilaku manusia saat ini lebih aktif berkolaborasi, hyper technology dan critical yakni terbiasa berfikir out of the box, kaya ide dan gagasan, confidence, yakni mereka sangat percaya diri dan berani mengungkapkan pendapat tanpa ragu-ragu, connected, yakni merupakan generasi yang pandai bersosialisasi, terutama dalam komunitas yang mereka ikuti, berselancar di sosial media dan internet (Nata, 2018: 10)

Dampak ketergantungan terhadap gadget, internet, dan media sosial telah mengakibatkan manusia menjadi pribadi yang malas, tidak membumi, kurang bersosialisasi, tidak suka bergotong royong, bahkan sampai melakukan imitasi terhadap budaya-budaya yang ada pada dunia maya. Padahal Indonesia sebagai bangsa Timur merupakan negara yang pada realita sejarahnya sangat memperhatikan budaya malu, gotong royong dan menjunjung nilai etik, moral dan agama serta tata karma.

Era disruptif harus dihadapi dan dijawab oleh dunia pendidikan. Menurut hemat penulis menghadapi dan menjawab tantangan era disruptif salah satu cara yang tepat adalah dengan menyemai dan memperkuat pondasi ilmu agama anak-anak melalui pendidikan agama di sekolah. Sebab dengan bekal pendidikan agama yang kokoh anakanak akan mampu memilah dan memilih informasi, budaya yang baik dan yang kurang baik akibat globalisasi di era disruptif tanpa harus ketinggalan zaman. 
Problemnya sekarang adalah apakah guru agama sudah memiliki bekal untuk mendidik siswa-siswa di era disruptif? Ataukah guru agama sendiri belum mengikuti perkembangan teknologi era disruptif, sehingga cara mengajarnya masih cenderung konvensional dan tidak inovatif. Lalu bagaimana pula sekolah sebagai satuan pendidikan mampukah menjawab tantangan di era disruptif.

\section{Paradigma Pendidikan Agama di Sekolah}

Paradigma pendidikan agama di sekolah di era disruptif harus berubah mengikuti kemajuan teknologi yang ada. Pendidikan agama di sekolah sudah tidak lagi hanya sebatas doktrin agama dan teknologi semata, melainkan juga mengikuti perkembangan sosial dan perilaku umat pada era global dengan budaya yang berbeda-beda yang dikaji dengan kajian agama. Dengan perubahan paradigma ini siswa diharapkan tidak hanya memiliki pengetahuan agama secara objektif dan tidak berdasar kepada pengetahuan dan iman subjektif belaka, tetapi juga membentuk karakter agama siswa tidak hanya sebatas kognitif semata.

Dalam taxonomy pendidikan sebagaimana dicetuskan oleh Bloom tersirat bahwa kecerdasan yang utama didasarkan pada keseimbangan tiga ranah yaitu kognitif, afektif dan psikomotorik (Bloom, Benjamin S, 1965). Kognitif meliputi domain pengetahuan, afektif merupakan domain karakter, dan psikomotorik adalah domain perilaku.

Pendidikan agama merupakan merupakan salah satu upaya membentuk karakter siswa. Pembentukan karakter siswa akan berimplikasi terhadap perilaku siswa. Mengingat pentingnya pembangunan karakter siswa maka seharusnya ada beberapa pihak yang bertanggung jawab 


\section{Pendidikan Agama Islam Pada Era Disruptif di Sekolah Berjejaring Sekolah Islam Terpadu}

dalam membentuk karakter siswa yaitu keluarga, sekolah, dan masyarakat. Namun seiring kemajuan zaman banyak orang tua yang menyerahkan pendidikan kepada sekolah termasuk pendidikan agamanya.

Pendidikan agama di sekolah menjadi sebuah problem manakala masih jauh dari peranannya dalam membangun karakter siswa dan moral bangsa. Masih banyak pendidikan agama di sekolah yang hanya menekankan kebenaran mutlak agama sendiri dan memandang agama lain sebagai salah dan sesat. Ia akan berpotensi pada pembentukan karakter dan perilaku siswa seperti melecehkan agama lain, intoleran, bahkan potensial memusuhi penganut agama lain.

Demikian pula pada proses pembelajaran dan pengajaran agama di sekola yang tak jarang menekankan pada ritualisme dan orientasi serba keakhiratan. Masih banyak proses pengajaran pendidikan agama yang belum mengaitkan keberagamaan dengan perilaku kongkrit duniawi seperti halnya kemajuan teknologi di era disruptif dimana banyak informasi berseliweran di dunia maya yang mudah diakses siswa melalui gadget, internet, dan media sosial.

Idealnya pendidikan agama di sekolah mampu melahirkan siswa-siswa yang memiliki kecerdasan ritual sekaligus kecerdasan sosial. Pendidikan agama yang diajarkan di sekolah sudah seharusnya selaras dengan regulasi pendidikan sehingga mampu mengantarkan siswa menjadi manusia yang beriman dan bertakwa kepada Tuhan yang Maha Esa. Dalam kerangka itu, pendidikan agama sebaiknya menjadikan siswa berperilaku terpuji, baik menyangkut hubungan vertikal dengan Tuhan maupun 
hubungan horizontal dengan sesama manusia (Wibowo, 2019: 29-43)

Pendidikan agama berusaha mengarahkan kepada pembentukan kepribadian anak-anak sesuai dengan ajaran agama. Pendidikan agama dilakukan dengan usaha-usaha sistematis dan pragmatis dalam membantu anak-anak agar hidup sesuai dengan ajaran agama(Shalahudin, 2001:8-9).

Berdasarkan beberapa kajian literatur yang ada pada website SIT diketahui bahwa SIT pada hakikatnya adalah sekolah yang mengimplementasikan konsep pendidikan Islam berlandaskan Alquran dan Sunnah. SIT merupakan konsep dan akumulasi proses pembudayaan, pewarisan pengembangan ajaran agama Islam, budaya serta peradaban Islam dari generasi ke generasi berikutnya (sditluqmanalhakim, 2019).

Istilah "Terpadu" dimaksudkan sebagai penguat (taukid) ajaran Islam itu sendiri. Maksudnya adalah ajaran Agama Islam yang kaafah, utuh menyeluruh, integral, tidak parsial, syumuliah tidak juga juz'iyah. Inilah sumber semangat utama dalam gerakan da'wah di bidang pendidikan untuk melawan pemahaman sekuler, dikotomi, juz'iyah (sditluqmanalhakim, 2019).

Pada implementasinya, SIT diartikan sebagai sekolah yang menerapkan pendekatan penyelenggaraan dengan memadukan pendidikan umum dan pendidikan agama menjadi satu jalinan kurikulum. Melalui pendekatan ini, semua mata pelajaran dan kegiatan sekolah tidak lepas dari "ruh" ajaran nilai-nilai Islam. Tidak ada dikotomi, tidak ada keterpisahan, tidak ada "sekularisasi" dimana pelajaran dan semua bahasan lepas dari nilai dan ajaran Islam, ataupun "sakralisasi" dimana Islam diajarkan terlepas dari konteks 


\section{Pendidikan Agama Islam Pada Era Disruptif di Sekolah Berjejaring}

kemaslahatan kehidupan masa kini dan masa depan. Pelajaran umum, seperti matematika, IPA, IPS, bahasa, jasmani/kesehatan, keterampilan dibingkai dengan pijakan, pedoman dan panduan Islam. Sementara di pelajaran agama, kurikulum diperkaya dengan pendekatan konteks kekinian dan kemanfaatan, dan kemaslahatan.

Pada perkembangannya SIT di Indonesia tergabung dalam beberapa organisasi. Beberapa diantaranya adalah SIT yang berjejeraing dengan Jaringan Sekolah Islam Terpadu (JSIT), Bina Anak Sholeh (BIAS), Maarif (NU), Pesantren, dan ada sekolah yang berdiri sendiri, tidak berafiliasi pada jaringan tertentu namun memakai istilah Islam terpadu. Namun demikian ada beberapa sekolah yang yang berafiliasi pada maarif tergabung dalam JSIT, dan sekolah lain bergabung dengan jaringan yang tidak satu yayasan dengan ormas tertentu.

\section{Metode}

Subyek penelitian dalam kajian ini adalah salah satu SMPIT di Kabupaten Semarang. SMPIT yang dijadikan subyek penelitian adalah sekolah yang berjejaring dengan Jaringan Sekolah Islam Terpadu (JSIT).

Jaringan Sekolah Islam Terpadu (JSIT) merupakan organisasi beranggotakan sekolah-sekolah Islam Terpadu dari seluruh Indonesia. Satuan pendidikan yang bergabung dalam JSIT mulai Taman Kanak-kanak Islam Terpadu (TKIT), Sekolah Dasar Islam Terpadu (SDIT), Sekolah Menengah Pertama Islam Terpadu (SMPIT), dan Sekolah Menengah Atas Islam Terpadu (SMAIT).

Jaringan Sekolah Islam Terpadu adalah wadah kerjasama efektif dalam pemberdayaan pengelolaan 
pendidikan.lembaga penyelenggara pendidikan anak usia dini, pendidikan dasar, pendidikan menengah, dan pendidikan tinggi yang menjadikan Islam sebagai landasan filosofis, konsepsional, operasional; dan menumbuhkan seluruh potensi fitrah peserta didik yang didukung oleh penyelenggara pendidikan, orangtua, masyarakat, pemerintah, dan lingkungan (JSIT, 2019).

\section{Temuan dan Pembahasan Setting wilayah}

Subyek penelitian ini adalah SMPIT Izzatul Islam yang berada di Kabupaten Semarang. Ada ketertarikan personal mengapa SMPIT ini diambil sebagai subyek penelitian, yaitu keberadannya di tengah masyarakat non muslim, banyak gereja dari berbagai denominasi baik besar maupun kecil di sekitar lokasi SMPIT. Hampir setiap gang jalan menuju lokasi ini ada gerejanya.

SMPIT ini dekat dengan puncak Gunung Merbabu, dari sekolah ini dapat terlihat puncak Gunung Merbabu dan Gunung Telomoyo. SMPIT Izzatul Islam sangat dekat dengan obyek Wisata Kopeng. Untuk sampai ke SMPIT Izzatul Islam dari arah Semarang harus melewati Kota Salatiga terlebih dahulu karena rute tercepat dari Ungaran adalah melalui Jalur Lingkar Salatiga (melewati IAIN Salatiga), melewati kawasan Salip Putih, dan Desa Sumogawe kemudian menuju Dukuh Pongangan, Samirono, dan Getasan. Batasbatas wilayah Getasan dapat dilihat dari Tabel 1.

Tabel 1 Batas Wilayah Kecataman Getasan

\begin{tabular}{ll}
\hline Posisi wilayah & Berbatasan dengan wilayah kab./kecamatan \\
\hline Batas sebelah Barat & KabupatenTemanggung \\
\hline & KabupatenMagelang \\
\hline Batas sebelahTimur & KecamatanTengaran \\
\hline
\end{tabular}


Pendidikan Agama Islam Pada Era Disruptif di Sekolah Berjejaring Sekolah Islam Terpadu

\begin{tabular}{ll}
\hline & KabupatenBoyolali, Kota Salatiga \\
\hline Batas sebelah Utara & KecamatanTuntang \\
\hline KecamatanBanyubiru \\
\hline Batas sebelah Selatan & KabupatenBoyolali \\
\hline
\end{tabular}

Dilihat dari komposisinya pemeluk agamanya, data yang diperoleh dari BPS Kabupaten Semarang diperoleh gambaran bahwa pemeluk beragama Islam masih menjadi pemeluk mayoritas di kecamatan ini, disusul oleh Kristen, Budha, dan Katolik.

Tabel 2. Jumlah Pendudukan Kabupaten Semarang Berdasar Agama

\begin{tabular}{ll}
\hline Agama & Jumlah \\
\hline Islam & 40.524 \\
\hline Kristen & 7.393 \\
\hline Buddha & 1.990 \\
\hline Katolik & 692 \\
\hline Khonghucu & 0 \\
\hline Lainnya & 27 \\
\hline
\end{tabular}

Sumber: BPS Kabupaten Semarang dalam angka 2017

Dilihat dari jumlah sekolahnya Kecamatan Getasan memiliki jumlah sekolah mulai dari TK-SMA sebagaimana

Tabel 3. Jumlah Sekolah di Kecamatan Getasam

\begin{tabular}{|c|c|c|c|c|c|c|c|c|}
\hline TK & & SD & & SMP & & SMA & & SMK \\
\hline Negeri & Swasta & Negeri & Swasta & Negeri & Swasta & Negeri & swasta & Negeri \\
\hline 0 & 35 & 25 & 8 & 3 & 4 & 1 & 0 & 0 \\
\hline
\end{tabular}

Sumber BPS Kabupaten Semarang dalam angka 2017

SMPIT Izzatul Islam mulai resmi beroperasi pada tanggal 20 Juni 2012, berada di bawah Yayasan Izzatul Islam yang mengelola pendidikan mulai dari TKIT, SDIT, dan SMPIT. Pada Ujian Nasional Tahun Ajaran 2017/2018 SMPIT Izzatul Islam meraih peringkat ke-3 nilai UN tingkat 
Kabupaten Semarang. Guru yang mengajar di SMPIT Izzatul Islam Getasan ini berjumlah 15 guru dan jumlah siswa sebanyak 192 siswa. Semua guru berstatus guru tetap yayasan.

SMPIT Izzatul Islam tergabung dalam JSIT wilayah Jawa Tengah. Mulai Tahun Pelajaran 2018/2019 SMPIT Izzatul Islam Getasan menggunakan Kurikulum 2013 khusus untuk kelas VII. Sedangkan kelas VIII dan IX masih menggunakan KTSP.

Perubahan kurikulum dari KTSP 2006 kepada Kurikulum 2013 didasarkan pada Permendikbud No. 81 A Tahun 2013 tentang Implementasi Kurikulum 2013 yang sudah mengalami penyempurnaan pada tahun 2016. Kurikulum 2013 dikembangkan sebagai langkah penyempurnaan Kurikulum berbasis Kompetensi (KBK) yang dirintis dan dilaksanakan pada tahun 2004 dan mengalamai penyempurnaan menjadi Kurikulum Tingkat Satuan Pendidikan (KTSP) tahun 2006. Penyempurnaan kurikulum tersebut meliputi keterpaduan antara kompetensi sikap, pengetahuan, dan keterampilan.

Menurut Kepala SMPIT Izzatul Islam, Muniroh, yang merujuk pada Dokumen Kurikulum SMPIT Izzatul Islam lahirnya Kurikulum 2013 tidak lepas dari adanya tantangan yang muncul berupa tantangan internal dan tantangan eksternal. Tantangan internal antara lain berupa tuntutan pendidikan yang mengacu kepada 8 Standar Nasional Pendidikan, meliputi Standar Pengelolaan, Standar Biaya, Standar Sarana Prasarana, Standar Pendidik dan Tenaga Kependidikan, Standar Isi, Standar Proses, Standar Penilaian, dan Standar Kompetensi Lulusan. 


\section{Pendidikan Agama Islam Pada Era Disruptif di Sekolah Berjejaring Sekolah Islam Terpadu}

Tantangan eksternal lahirnya Kurikulum 2013 menurut Muniroh adalah faktor perkembangan penduduk Indonesia dilihat dari pertumbuhan penduduk usia produktif. Merujuk pada dokumen kurikulum sekolahnya, Muniroh menjelaskan bahwa tantangan eksternal digolongkan menjadi 3 macam, yaitu tantangan masa depan, kompetensi masa depan, persepsi masyarakat, perkembangan pengetahuan dan pedagogi, dan fenomena negatif yang mengemuka. Tantangan masa depan dapat berupa globalisasi, kemajuan teknologi informasi, konvergensi ilmu dan teknologi, ekonomi berbasis pengetahuan, dan budaya. Pergeseran kekuatan ekonomi dunia, mutu investasi dan transformasi pada sektor pendidikan, dan materi TIMSS (Trend in International Mathematics and Science Study) dan PISA (Program international for Student Assessment) menurut Muniroh juga merupakan tantangan eksternal yang harus diantisipasi.

Lebih lanjut, Muniroh mengungkap kompetensi masa depan meliputi kemampuan berkomunikasi, kemampuan berpikir jernih dan kritis, kemampuan mempertimbangkan segi moral suatu permasalahan, kemampuan menjadi warga negara yang bertanggungjawab. Kompetensi masa depan lainnya menurut Dokumen Kurikukulm 2013 SMPIT Izzatul Islam adalah kompetensi dalam hal kemampuan mencoba untuk mengerti dan toleran terhadap pandangan yang berbeda, kemampuan hidup dalam bermasyarakat di era global mengglobal, memiliki kecakapan dan kesiapan untuk bekerja, memiliki kecerdasan sesuai dengan bakat/ minatnya, dan memiliki rasa tanggungjawab terhadap lingkungan (Dokumen I KTSP SMPIT Izzatul Islam). 
Persepsi masyarakat antara lain terlalu menitikberatkan pada aspek kognitif, beban siswa terlalu berat, dan kurang bermuatan karakter. Perkembangan pengetahuan dan pedagogi meliputi neurologi, psikologi, discovery learning, dan collaborative learning. Fenomena negatif yang mengemuka misalnya perkelahian antarpelajar, plagiarisme, penyalahgunaan narkoba, korupsi, kecurangan dalam mengerjakan ujian dan gejolak masyarakat (Dokumen Kurikulum SMPIT Izzatul Islam).

SMPIT Izzatul Islam Getasan sebagai sebuah satuan pendidikan di tingkat dasar dengan segala keunggulan dan kelemahan bertekad untuk melakukan perubahan kurikulum demi terwujudnya insan kamil sesuai dengan visi misi yang hendak dicapai. Pelaksanaan Kurikulum 2013 di SMPIT Izzatul Islam Getasan diharapkan dapat menjadi acuan dan penggerak utama untuk menciptakan generasi Islami yang tidak hanya cerdas secara intelektual tetapi juga cerdas secara akhlak dan mandiri. Segenap keluarga besar SMPIT Izzatul Islam Getasan yang meliputi pengurus yayasan, dewan guru, karyawan, dan komite berharap pelaksanaan Kurikulum 2013 dapat berjalan maksimal sesuai dengan tujuan pendidikan nasional.

Tujuan penyusunan Kurikulum SMPIT Izzatul Islam Getasan disusun sebagai acuan pelaksanaan pendidikan, pembelajaran, dan penilaian di SMPIT Izzatul Islam Getasan. Ada 13 acuan konseptual Kurikulum SMPIT Izzatul Islam Getasan dalam menyusun Kurikulum 2013. Acuan koseptual tersebut oleh peneliti kemudian dikategorikan menjadi lima.

Pertama, peningkatan iman, takwa, dan akhlak mulia harus menjadi dasar pembentukan kepribadian peserta 


\section{Pendidikan Agama Islam Pada Era Disruptif di Sekolah Berjejaring Sekolah Islam Terpadu}

didik secara utuh. Oleh karena itu kurikulum sekolah harus disusun agar memungkinkan semua mata pelajaran dapat menunjang peningkatan iman dan takwa serta akhlak mulia peserta didik (Dokumen Kuruikulum SMPIT Izzatul Islam).

Kedua, kebutuhan kompetensi masa depan. Dalam era globalisasi dituntut generasi yang berkompeten agar di masa mendatang mampu bersaing dengan bangsa lain dalam segala aspek kehidupan sehingga terwujud masyarakat yang tangguh, mandiri, dan berdaya saing tinggi. Peningkatan potensi, kecerdasan, bakat, dan minat sesuai dengan tingkat perkembangan peserta didik. Kurikulum SMPIT Izzatul Islam disusun dalam rangka mengembangkan keragaman potensi, minat, kecerdasan intelektual, emosional, spiritual, dan kinestetik peserta didiknya sesuai dengan tingkat perkembangannya. Keragaman potensi dan karakteristik daerah serta lingkungan merupakan potensi, kebutuhan, tantangan, dan keragaman karakteristik lingkungan. Oleh karena itu kurikulum harus memuat keragaman tersebut untuk menghasilkan lulusan yang dapat memberikan kontribusi untuk pengembangan daerah.

Ketiga, tuntutan pembangunan daerah dan nasional yang harus memperhatikan keseimbangan antara pembangunan nasional dan daerah. Kurikulum harus memuat kecakapan hidup untuk membekali peserta didik memasuki dunia kerja sesuai dengan tingkat perkembangan peserta didik dan kebutuhan dunia kerja, khususnya bagi mereka yang tidak melanjutkan ke jenjang yang lebih tinggi. Perkembangan ilmu pengetahuan, teknologi, dan seni mengharuskan kurikulum dikembangkan secara berkala dan berkesinambungan sesuai dengan perkembangan ilmu pengetahuan, teknologi, dan seni. 
Keempat, kurikulum harus mempertimbangkan toleransi dan kerukunan umat beragama serta memperhatikan norma agama yang berlaku di satuan pendidikan. Oleh karena itu Kurikulum SMPIT Izzatul Islam dikembangkan dan disesuaikan dengan kondisi sosial budaya masyarakat Getasan. Kurikulum harus dikembangkan dengan memperhatikan karakteristik sosial budaya masyarakat setempat dan menunjang kelestarian keragaman budaya dan diarahkan kepada pendidikan yang berkeadilan dan mendorong tumbuh kembangnya kesetaraan gender.

Kelima, dinamika perkembangan global. Kurikulum harus dikembangkan agar peserta didik mampu bersaing secara global dan dapat berdampingan dengan bangsa lainnya. Persatuan nasional dan nilai-nilai kebangsaan mengharuskan kurikulum didorong untuk menumbuhkan sikap kebangsaan dan persatuan nasional dalam rangka memperkuat keutuhan bangsa dalam negara kesatuan republik Indonesia.

Pengembangan Kurikulum di SMPIT Izzatul Islam berpegang pada tujuh prinsip. Berdasarkan dokumen kurikulum sekolah, ketujuh prinsip tersebut adalah sebagai berikut.

Pertama, kurikulum SMPIT Izzatul Islam berprinsip bahwa peserta didik sebagai posisi sentral dengan tujuan agar kompetensinya berkembang menjadi manusia beriman dan bertakwa kepada Allah, berakhlak mulia, sehat, berilmu, mandiri, kreatif, dan menjadi warga negara yang demokratis serta bertanggung jawab. Sebagai usaha mencapai tujuan tersebut maka pengembangan kurikulum diarahkan 


\section{Pendidikan Agama Islam Pada Era Disruptif di Sekolah Berjejaring Sekolah Islam Terpadu}

sesuai dengan potensi perkembangan, kebutuhan, tuntutan lingkungan dan kepentingan siswa.

Kedua, beragam dan terpadu, yaitu kurikulum yang dikembangkan dengan memperhatikan keragaman karakteristik siswa dilihat dari kedaerahan, jenjang dan jenis pendidikan, perbedaan agama, suku, budaya, adat istiadat, status sosial ekonomi, dan gender. SMPIT Izzatul Islam menyusun kurikulum berdasarkan pengembangan diri secara terpadu, serta disusun berdasarkan keterkaitan dan kesinambungan yang bermakna dan tepat antar substansi.

Ketiga, tanggap terhadap perkembangan ilmu pengetahuan, teknologi, dan seni. Kurikulum dikembangkan atas dasar kesadaran bahwa ilmu pengetahuan teknologi dan seni berkembang secara dinamis. Semangat dan isi Kurikulum SMPIT Izzatul Islam berusaha memberikan pengalaman belajar peserta didiknya untuk mengikuti dan memanfaatkan perkembangan ilmu pengetahuan, teknologi, dan seni.

Keempat, relevan dengan kebutuhan kehidupan. Maksudnya adalah pengembangan kurikulum disusun dan dilaksanakan dengan melibatkan stakeholders dalam usaha menjamin relevansi antara pendidikan di SMPIT dengan kebutuhan kehidupan. Oleh karena itu, Kurikulum SMPIT disusun dengan memperhatikan pengembangan keterampilan pribadi, keterampilan berpikir, keterampilan sosial, keterampilan akademik, dan keterampilan vokasional.

Kelima, menyeluruh dan berkesinambungan. Artinya substansi kurikulum harus mencakup keseluruhan dimensi kompetensi bidang kajian.

Keenam, Kurikulum SMPIT Izzatul Islam diarahkan pada proses belajar sepanjang hayat dengan memperhatikan 
proses pengembangan, pembudayaan, dan pemberdayaan peserta didik yang berlangsung sepanjang hayat. Kurikulum SMPIT berusaha mencerminkan keterkaitan antar unsurunsur pendidikan formal, nonformal, dan informal dengan memperhatikan kondisi dan tuntutan lingkungan yang selalu berkembang serta arah pengembangan manusia seutuhnya.

Ketujuh, Kurikulum SMPIT Izzatul Islam berusaha mengembangkan pendidikan dengan memperhatikan kepentingan nasional dan kepentingan daerah untuk membangun kehidupan bermasyarakat, berbangsa, dan bernegara. Hal ini selaras dengan idealisme bahwa kepentingan nasional dan kepentingan daerah harus saling mengisi dan memberdayakan dalam kerangka Negara Kesatuan Republik Indonesia.

Berdasarkan pada pengumpulan data diperoleh gambaran bahwa kurikulum yang disusun oleh sekolah memungkinkan melakukan penyesuaian program pendidikan dengan kebutuhan dan potensi yang ada di sekolah. Sebagai unit penyelenggara satuan pendidikan, SMPIT Izzatul Islam berusaha memperhatikan perkembangan dan tantangan masa depan siswanya, misalnya menyangkut perkembangan ilmu pengetahuan dan teknologi, globalisasi, era informasi, dan perubahan kesadaran masyarakat dan orang tua pada dunia pendidikan.

“Tantangan sekaligus peluang itu harus direspon oleh sekolah kami, sehingga visi sekolah diharapkan sesuai dengan arah perkembangan tersebut. Visi tidak lain merupakan citra moral yang menggambarkan profil sekolah yang diinginkan di masa datang. Visi sekolah tetap dalam koridor kebijakan pendidikan nasional. Visi juga harus memperhatikan dan 


\section{Pendidikan Agama Islam Pada Era Disruptif di Sekolah Berjejaring Sekolah Islam Terpadu}

mempertimbangkan potensi yang dimiliki sekolah dan harapan masyarakat yang dilayani sekolah," tutur Muniroh.

Muniroh mengungkapkan bahwa dalam merumuskan visi, pihak-pihak yang terkait (stakeholders) bermusyawarah sehingga visi sekolah mewakili aspirasi berbagai kelompok yang terkait sehingga seluruh kelompok yang terkait (guru, karyawan, siswa, orang tua, masyarakat, pemerintah) bersama-sama berperan aktif mewujudkannya. Visi adalah gambaran satuan pendidikan yang dicita-citakan, sebagai imajinasi moral untuk menumbuhkan inspirasi, semangat, dan komitmen warganya dalam koridor pembangunan nasional, serta realistis sesuai harapan masyarakat.Visi pada umumnya dirumuskan dengan kalimat (1) filosofis, (2) khas, (3) mudah diingat. Berdasarkan pertimbangan di atas maka Visi SMPIT Izzatul Islam Getasan Kabupaten Semarang adalah "mewujudkan generasi sholih, ilmuwan, pemimpin kreatif, dan smart".

Visi SMPIT Izzatul Islam Getasan adalah terwujudnya segenap warga SMPIT Izzatul Islam Getasan yang sholih, ilmuwan, pemimpin kreatif, dan smart (SIPKS). Indikator karakter ketercapaian visi (bagi guru dan tenaga administrasi sekolah) adalah sebagai berikut.

Pertama, sholih yaitu setiap warga SMPIT harus membudayakan perilaku saleh. Perilaku saleh tersebut ada dalam indikator visi SMPIT yaitu mengerjakan setiap perintah Allah, menjauhi larangan Allah, bersyukur atas setiap nikmat dengan cara beramal kebaikan, mengucapkan doa setiap memulai dan mengakhiri setiap kegiatan, menyesal setiap berbuat kesalahan dan segera mohon ampun kepada Tuhan, serta tidak mengulanginya. 


\section{A.M. Wibowo}

Kedua, ilmuwan, setiap warga SMPIT harus membudayakan prinsi-prinsip ilmuwan. Prinsip ilmuwan tersebut ada dalam indikator visi ilmuwan SMPIT yaitu: memiliki kecintaan terhadap ilmu pengetahuan, memiliki cara berpikir, bersikap dan berbuat yang menunjukkan kesetiaan, kepedulian, dan penghargaan yang tinggi terhadap pengetahuan, memiliki ketekunan, tidak mudah menyerah, sabar, teliti, dan sikap mencurahkan pikiran pada satu tujuan, menambah ilmu dengan berbagai cara yang sesuai peraturan dan logika, memiliki imajinasi yang dibutuhkan dalam pemecahan masalah sehari-hari, mencari informasi baru melalui media yang ada dan mengikuti perkembangan ilmu, sikap selalu ingin tahu lebih banyak, tidak puas terhadap informasi atau penjelasan yang hanya menyentuh kulit luar suatu permasalahan, mempunyai pandangan luas, terbuka, bebas dari prasangka, menjadi tempat bertanya peserta didik, teman atau orang lain, berusaha memecahkan masalah dalam melaksanakan tugas pokok dan fungsinya berdasarkan konsep keilmuwan. Selain itu ada tiga indikator ilmuwan lainnya seperti; rasional dalam berbicara dan bertindak, mengerjakan tugas pokok dan fungsinya secara baik dan benar, dan bersikap efisien dan efektif dalam melaksanakan tugas pokok dan fungsinya.

Ketiga, pemimpin, setiap warga SMPIT harus membudayakan prinsip pemimpin. Prinsip pemimpin tersebut ada dalam indikator visi pemimpin SMPIT yaitu: mampu mengendalikan diri sendiri dan orang lain, membuat keputusan dan menyelesaikan masalah dengan bijak, mampu memberi keteladanan kebaikan, menghargai perbedaan dan pendapat orang lain, melaksanakan 


\section{Pendidikan Agama Islam Pada Era Disruptif di Sekolah Berjejaring Sekolah Islam Terpadu}

kewajiban dengan penuh tanggung jawab, memiliki tenggang rasa dan wawasan yang luas, dan menghargai kerja orang lain sesuai hasil karyanya.

Keempat, kreatif inovatif, setiap warga SMPIT harus membudayakan prinsip kreatif inovatif. Prinsip kreatif inovatif tersebut ada dalam indikator kreatif inovatif SMPIT Izzatul Islam, yaitu: menerima sesuatu yang baru, bersikap terbuka dalam menerima dan memberi pendapat, membuat pertimbangan berdasarkan alasan dan bukti, serta berani memberi pandangan dan kritikan berkaitan tugas pokok dan fungsinya, mengaplikasikan sikap, pengetahuan, keterampilan, dan pengalaman dalam melaksanakan tugas pokok dan fungsinya, mampu menggunakan pikiran untuk menghasilkan ide, tidak puas jika sekedar meniru orang lain. Selain itu warga SMPIT Izzatul Islam harus menghasilkan ide atau gagasan baru yang lebih baik, berpikir dan melaksanakan sesuatu untuk menghasilkan cara atau hasil baru dari apa yang telah dimiliki dalam melaksanakan tugas pokok dan fungsinya, mampu berkarya dalam melaksanakan tugas pokok dan fungsinya.

Kelima, smart (cerdas), setiap warga SMPIT harus membudayakan prinsip smart. Prinsip smart tersebut ada dalam indikator visi smart SMPIT yaitu: memiliki wawasan dan pandangan yang luas dan kedepan, memanfaatkan waktu dan kesempatan secara efektif dan efisien dalam belajar, mampu memanfaatkan sumber belajar, memiliki semangat untuk menambah ilmu, dan mampu memanfaatkan ilmu yang telah diperoleh.

SMPIT Izzatul Islam menetapkan beberapa indikator ketercapaian visi bagi peserta didiknya. Ada lima indikator 
peserta didik mencapai visi SMPIT yaitu sholih, ilmuwan, pemimpin, kreatif inovatif, dan smart atau cerdas.

Peserta didik dinyatakan telah sholih manakala siswa telah mengerjakan setiap perintah Allah dan menjauhi larangannya, disamping peserta didik selalu mengikuti mata pelajaran pendidikan agama Islam dan rumpunnya. Sholih juga berarti siswa senantiasa bersyukur atas setiap nikmat yang telah diberikan Allah dengan cara mengucap syukur dan berdoa setiap memulai dan mengakhiri pelajaran di sekolah. Disamping itu, peserta didik berusaha untuk menghindari dan menolak setiap ajakan untuk melakukan perbuatan tercela. Seandainya melakukan perbuatan tercela maka peserta didik merasa menyesal dan segera mohon ampun kepada Tuhan, serta tidak mengulanginya.

Peserta didik telah mencapai derajat ilmuwan sesuai visi SMPIT Izzatul Islam manakala siswa telah memiliki kecintaan terhadap ilmu pengetahuan sehingga mendorong produktifitas sangat besar. Siswa juga memiliki cara berpikir, bersikap, dan berbuat yang menunjukkan kesetiaan, kepedulian, dan penghargaan yang tinggi terhadap pengetahuan. Siswa juga memiliki ketekunan, tidak mudah menyerah, sabar, teliti, dan sikap mencurahkan pikiran pada satu tujuan belajar. Untuk mencapai itu maka siswa senantiasa memperbanyak literasi guna menambah ilmu dengan berbagai cara yang sesuai peraturan dan logika.

SMPIT Izzatul Islam dalam usaha mencapai visi ilmuwan bagi peserta didiknya juga melakukan stimulan kepada siswa agar memiliki imajinasi dalam pemecahan masalah sehari-hari. Caranya adalah dengan cara mencari informasi baru melalui media yang ada dan mengikuti 


\section{Pendidikan Agama Islam Pada Era Disruptif di Sekolah Berjejaring Sekolah Islam Terpadu}

perkembangan ilmu. Tentu saja didorong oleh kesadaran dan sikap selalu ingin tahu lebih banyak dan tidak puas terhadap informasi atau penjelasan yang hanya menyentuh kulit luar suatu permasalahan. Peserta didik juga dirangsang untuk berpandangan yang luas, terbuka, dan bebas dari prasangka.

Harapannya jika visi ilmuwan telah berjalan dengan semestinya siswa akan berusaha memecahkan masalah dalam melaksanakan tugas pokok dan fungsinya berdasarkan konsep keilmuwan, menjadi tempat bertanya bagi teman lainnya, rasional dalam berbicara dan bertindak serta mampu mengerjakan tugas pokok dan fungsinya secara baik dan benar. Harapannya adalah peserta didik nantinya mampu bersikap efisien dan efektif dalam melaksanakan tugas pokok dan fungsinya.

SMPIT Izzatul Islam dalam usaha mencapai visi pemimpin bagi peserta didiknya memiliki tujuh dimensi, yaitu melaksanakan kewajiban belajar dengan baik, tidak ingin mendapat lebih atas sesuatu yang bukan haknya. Peserta didik mampu meletakkan sesuatu menurut tempatnya, memperlakukan orang lain atas dasar kebenaran dan haknya, membela orang lain yang diperlakukan tidak adil, tidak membeda-bedakan dalam pergaulan, menghargai kerja orang lain sesuai hasil karyanya. Untuk mewujudkan hal tersebut maka sekolah perlu melakukan latihan kepemimpinan dalam organisasi siswa intra sekolah.

SMPIT Izzatul Islam dalam usaha mencapai visi kreatif inovatif bagi peserta didiknya memiliki delapan indikator, yaitu mampu bersikap terbuka dalam menerima dan memberi pendapat, membuat pertimbangan berdasarkan 
alasan dan bukti, serta berani memberi pandangan dan kritikan berkaitan tugas belajar, dan mengaplikasikan sikap, pengetahuan, keterampilan, dan pengalaman dalam melaksanakan tugas belajar. Peserta didik juga mampu menggunakan pikiran untuk menghasilkan ide asli, tidak puas jika sekedar meniru orang lain, menerima sesuatu yang baru, dan menghasilkan ide atau gagasan baru yang lebih baik. Peserta diidk juga mampu berpikir dan melaksanakan sesuatu untuk menghasilkan cara atau hasil baru dari apa yang telah dimiliki dalam melaksanakan tugas belajar, yang pada akhirnya mampu berkarya dalam melaksanakan tugas belajar.

SMPIT Izzatul Islam dalam usaha mencapai visi smart-cerdas bagi peserta didiknya memiliki delapan indikator, yaitu: gemar membaca, komitmen untuk belajar, mengerjakan setiap tugas yang diberikan guru dengan sebaik mungkin, memiliki komitmen kuat dalam berprestasi, memiliki prestasi akademik dan non akademik, senang dalam kegiatan yang bersifat kompetitif, tidak cepat menyerah bila mengalami kesulitan belajar, serta mencari informasi terkini dalam pembelajaran.

\section{Kegiatan Pembelajaran}

Kegiatan harian di SMPIT Izzatul Islam Getasan adalah kegiatan yang wajib diikuti semua siswa pada jam sekolah atau belajar. Kegiatan sehari-hari yang diikuti seluruh siswa SMPIT Izzatul Islam Getasan meliputi: sambut siswa, salat Duha, Tilawah Qur'an guru dan siswa, makan siang, Tahfizh Alquran, Murajaah juz 29 dan 30, upacara/apel pagi, salat zuhur berjamaah, bina kelas dan motivasi, kultum, KBM, evaluasi, dan doa. 


\section{Pendidikan Agama Islam Pada Era Disruptif di Sekolah Berjejaring Sekolah Islam Terpadu}

Program unggulam SMPIT Izzatul Islam meliputi: Reading Al-Qur'an everyday, Outbond, Mentoring (pembinaan karakter) 8 Classmeeting, Mabit dan Pesantren Ramadhan, Training Motivasi, Leadership Training, Camping (kemah), Pembinaan Olimpiade, Study Tour, Social Care Day (bakti sosial)

Kegiatan ekstrakurikuler SMPIT Izzatul Islam masuk dalam kegiatan muatan lokal dan pengembangan diri. Ada dua jenis kegiatan ekstrakurikuler yaitu wajib dan pilihan. Ekstrakurikuler yang wajib bagi siswa SMPIT Izzatul Islam meliputi Pramuka dan Panahan. Muatan lokal di SMPIT meliputi Bahasa Arab dengan jumlah jam pelajaran sebanyak 2 jam pelajaran, Baca Tulis Alquran dengan menggunakan Metode Ummi 10 jam perminggu. Disamping itu masih ada ekstrakurikuler yang menjadi pilihan peserta didik yaitu qiro'ah, sepak bola, bola volley dan melukis.

Implementasi PAI di SMPIT Izzatul Islam dalam Menyongsong Era Disruptif

Era disruptif tidak bisa dihindari, oleh karena itu perlu strategi dalam menyongsong era disruptif ini. Ada beberapa stretegi pembelajaran di SMPIT Izzatul Islam. SMPIT Izzatul Islam memberlakukan dua kurikulum, yaitu Kurikulum 2013 untuk kelas VII dan Kurikulum 2006 untuk kelas VIII dan IX. Alokasi jam pepalajaran PAI dan Budi Pekerti adalah 3 JP untuk Kurikulum 2013 dan 2 jam untuk Kurikulum 2006.

Kurikulum PAI dan Budi Pekerti di SMPIT Izzatul Islam adalah murni kurikulum Dinas/kemendikbud, tidak dipecah menjadi rumpun mata pelajaran PAI seperti Alquran Hadis, Fikih, SKI, dan Akidah Akhlak. Hal tersebut, menurut Insan 
Abdullah, guru PAI Izzatul Islam, karena SMPIT Izatul Islam adalah di bawah wewenang Kementerian Pendidikan dan Kebudayaan.

Namun demikian Kurikulum PAI dari Diknas tidak cukup untuk memperkuat karakter, akidah dan akhlak siswa. Oleh karena itu dalam rangka memperkuat akidah, akhlak, dan karakter siswa maka SMPIT memberikan tambahan baik dalam intrakurikuler, ekstrakurikuler maupun muatan lokal sekolah. Tambahan-tambahan tersebut meliputi Boarding School untuk kelas VIII dan IX, Dirosah Islamiyah setiap hari, Tahfizh, BTQ dengan metode Ummi, Salat Duha wajib ditambah tausiyah guru, salat zuhur wajib berjamaah dilanjut tausiyah oleh siswa, dan kajian Islam berupa sirah nabawiyah, sahabat dan sejarah Islam lainnya.

Guru PAI SMPIT Izzatul Islam diampu oleh satu orang yaitu Insan Abdullah. Ia merupakan Alumni D3 LIPIA Jakarta Bahasa Arab yang kemudian melanjutkan pendidikan S1 Tarbiyah di STAINDO Jakarta. Selain mengenyam pendidikan formal, Insan Abdullah juga pernah mengenyam pendidikan di pondok Pesantren Al-Irsyad Salatiga, namun saat ini ia tidak pernah aktif dalam kepengurusan Al-Irsyad. Insan Abdullah telah mengajar di sekolah ini dua tahun setelah SMPIT ini berdiri, yaitu tahun 2014. Sampai sekarang ia belum memiliki sertifikat guru sehingga belum menerima sertifikasi.

Guru PAI Izzatul Islam mengajar PAI di sembilan kelas selama 1 minggu. Selain mengajar PAI ia juga masuk dalam tim guru untuk memberikan pendidikan Dirosah Islamiah, Bahasa Arab, BTA, dan tahfizh. 


\section{Pendidikan Agama Islam Pada Era Disruptif di Sekolah Berjejaring Sekolah Islam Terpadu}

Dalam menyusun Kurikulum PAI, Guru PAI Izzatul Islam bersama-sama MGMP guru PAI Getasan menyusun garis-garis besarnya secara bersama-sama. Namun dalam implementasi di sekolah, Kurikulum PAI SMPIT Izzatul Islam ditambah dengan muatan-muatan Islam terpadu sehingga menurut Insan Abdullah lebih tinggi dari Kurikulum PAI yang disusun bersama-sama dengan MGMP PAI.

Hal ini dikarenakan sekolah ini berbasis Islam Terpadu sehingga nilai-nilai Islam terpadunya harus terimplementasi dalam pembelajaran. Contoh ke-IT-annya terletak pada bacaan Qurannya. Insan menyadari bahwa masih banyak siswa SMPIT yang belum bisa membaca Quran dengan baik dan benar, oleh karena itu harus dilakukan perbaikanperbaikan untuk siswa SMPIT. Dalam implementasi pembelajaran PAI, guru PAI juga memberikan penguatan Quran, Hadis, SKI, Akidah Akhlak, dan Fikih.

Terlebih siswa SMPIT Izzatul Islam memiliki target untuk hafal Alquran juz 30, sehingga perlu penguatanpenguatan terhadap Alquran dan pelajaran PAI disamping dirosah Islamiyah, dan intrakurikuler BTA dengan metode Ummi. Metode Ummi adalah metode yang dikembangkan oleh Ummi Foundation untuk menjamin mutu kualitas bacaan Alquran.

Metode ini dilakukan dengan cara dirrect method, repetition, dan affection. Direct method (langsung) yaitu langsung dibaca tanpa dieja/diurai atau tidak banyak penjelasan, atau dengan kata lain learning by doing, belajar dengan melakukan secara langsung. Repetition (diulangulang), bacaan Alquran akan semakin kelihatan keindahan, kekuatan, dan kemudahannya ketika kita mengulang-ulang 
ayat atau surat dalam Alquran. Begitu pula seorang ibu dalam mengajarkan bahasa kepada anaknya. Kekuatan, keindahan, dan kemudahannya juga dengan mengulangulang kata atau kalimat dalam situasi dan kondisi yang berbeda-beda. Affection (kasih sayang yang tulus) kekuatan cinta, kasih sayang yang tulus, dan kesabaran seorang ibu dalam mendidik anak adalah kunci kesuksesannya. Demikian juga seorang guru yang mengajar Alquran jika ingin sukses hendaknya meneladani seorang ibu agar guru juga dapat menyentuh hati siswa mereka (www.ummifoundation. org, 2019).

Penguatan Spiritual, Sosial, Pengetahuan, dan Keterampilan Siswa

Penguatan nilai-nilai spiritual dan sosial siswa dilakukan oleh SMPIT Izzatul Islam dalam rangka mempersiapkan siswa menyongsong era disruptif, baik setelah lulus SMP maupun setelah dewasa kelak. Penguatan spiritual dan sosial siswa tersebut dilakukan dengan cara menanamkan karakter yang harus dimiliki oleh siswa. Karakter tersebut meliputi dapat dipercaya, memiliki rasa hormat dan perhatian, tekun, bertanggung jawab, mampu bekerjasama, memiliki rasa cita kepada sesama manusia dan lingkungan, dan kemanusiaan. Semuanya diramu dan dibingkai dalam motto SIPKS (Sholih, Ilmuwan, Pemimpin Kreatif dan Smart) yang menjadi motto SMPIT Izzatul Islam.

Penguatan nilai-nilai spiritual dan sosial di SMPIT Izzatul Islam ini dilakukan baik di dalam proses pembelajaran di kelas maupun di luar kelas. Di dalam kelas penguatan nilai-nilai spiritual diberikan dengan memberikan materi 


\section{Pendidikan Agama Islam Pada Era Disruptif di Sekolah Berjejaring Sekolah Islam Terpadu}

sesuai dengan kurikulum dengan diperkuat contoh-contoh sebagai teladan siswa. Di luar sekolah kelas dilakukan melalui kegiatan-kegiatan dan budaya sekolah dan boarding school. Seperti contoh murojaah, salat duha, tausiyah pagi, salat zuhur berjamaah dan tausiyah, dan lain sebagainya. Tujuannya agar siswa dapat menerima siraman rohani dalam kehidupan sehari-hari di kelas maupun di luar kelas. Dengan siraman rohani ini diharapkan akan mengendap dalam pribadi siswa dan menjadi habituasi dalam kehidupan sehari-hari dan kelak setelah siswa lulus. Penanaman nilai spiritual ini diharapkan mampu memperbaiki sikap sosial, pengetahuan, dan keterampilam siswa.

Penguatan spiritual dan sosial siswa merupakan bentuk laporan guru kepada sekolah dan kepada orang tua. Penilaian ini menjadi acuan atau menjadi kontrol sekolah dalam rangka menentukan langkah apabila ada siswa yang membutuhkan bimbingan lebih. Teknik penilaian ini dilakukan dengan membuat rubrik penilaian baik berupa observasi, penilaian diri, dan penilaian antarteman. Setiap siswa memiliki laporan untuk penguatan spiritual yang dilakukan pada saat pembelajaran dan setelah pembelajaran usai.

Sikap-sikap spiritual dan sosial yang ditanamkan kepada siswa antara lain kebiasaan untuk membaca Alquran (tadarus), kebiasaaan berdoa sebelum dan sesudah melakukan sesuatu (pelajaran dan kegiatan lainnya), menghormati pemeluk agama yang berbeda, melaksanakan ibadah tepat pada waktunya, dan kebiasaan mengucapkan salam. Membaca Alquran akan melahirkan sikap spriritual tentang keyakinan keimanan terhadap Allah SWT. Dengan tadarus juga akan melahirkan sikap spiritual keyakinan 
bahwa ilmu pengetahuan bersumber dari Allah swt. Dengan keyakinan bahwa sumber ilmu berasal dari Allah maka akan menguatkan siswa untuk belajar dengan tekun karena Tuhan memuliakan orang yang berilmu.

Penguatan nilai-nilai spiritual siswa memiliki harapan untuk dapat menguatkan pula nilai-nilai siswa pada aspek sosialnya. Beberapa indikator yang diharapkan terhadap penguatan sikap sosial siswa SMPIT Izzatul Islam antara lain memiliki semangat yang tinggi dan sungguh-sungguh dalam belajar, mengajarkan ilmu kepada teman atau orang lain yang membutuhkan, mampu menjawab ketika ada yang bertanya, tidak membanggakan diri karena ilmu yang dimilikinya, serta tidak membeda-bedakan pergaulan atas dasar kepandaian yang dimiliknya.

\section{Penutup}

Dari uraian di atas dapat ditarik kesimpulan tentang impelementasi PAI pada sekolah berjejaring dengan Sekolah Islam Terpadu menyongsong era disruptif. Kesimpulan tersebut adalah bahwa SMPIT Izzatul Islam di Kabupaten Semarang mempersiapkan dan membekali siswa dengan pengimplementasikan dan mengiternalisasikan Pendidikan Agama Islam dalam setiap kegiatan di sekolah, baik melalui budaya sekolah, kurikulum sekolah, kurikulum pendidikan, ektrakurikuler, kegitan pembelajaran dan kegiatan harian baik di sekolah maupun melalui boarding school.

Implementasi dan internalisasi pendidikan agama tersebut dilakukan dalam rangka membentuk karakter siswa untuk menghadapi era disruptif. Karakter yang dibentuk adalah siswa berkarakter Sholih, Ilmuwan, Pemimpin Kreatif dan Smart (SIPKS) sesuai dengan indikator karakter ketercapaian visi sekolah. 


\section{Pendidikan Agama Islam Pada Era Disruptif di Sekolah Berjejaring \\ Sekolah Islam Terpadu}

\section{DAFTAR PUSTAKA}

Bloom, Benjamin S, D. 1965. Taxonomy of Educational Objectives : The Classification of Educational Goals, Handbook I Cognitive Domain. New York: Longmans, Green and Co.

Christensen, C, M. 1997. The Innovator's Dilemma: The Revolutionary Book that Will Change the Way You Do Bussiness. Boston: Harvard Business School Press.

D. Mariamba, A. 1989. Pengantar Filsafat Pendidikan Islam. Bandung: Al Maarif.

"SDIT Lukman al Hakim". Retrieved from http:// sditluqmanalhakim-jogja.sch.id/home/readmore/16. diakses April 2019.

JSIT. 2019. Arti Nama JSIT. Retrieved from JSIT website: https:/ / jsit-indonesia.com/sample-page/arti-nama-lambangorganisasi/ diakses 13 Oktober 2019

Khuzaimah. 2017. Paradigma Pengembangan Kurikulum Pendidikan Agama Islam di Sekolah (Analisis berbagai Kritik terhadap PAI. Jurnal Kependidikan, Vol 5 No. 1. Halaman 81-90.

Nata, A. 2018. Pendidikan Islam Era Milenial. Junla Conciencia, Vol. 18 No. 1 Halaman 10-28.

Priatmoko, S. 2018. Memperkuat Eksistensi Pendidikan Islam di Era 4.0. Ta'lim Jurnal Studi Pendidikan Islam. Vol. 1 No. 2. Halaman 1-19.

Shalahudin, M. 2001. Metodologi Pendidikan Agama. Surabaya: Bina Ilmu. 
Tafsir, A. 2005. Ilmu Pendidikan Dalam Persektif Islam. Bandung: Remaja Rosdakarya.

Tilaar, H. 2005. Manifesto Pendidikan Nasional. Jakarta: Buku Kompas.

Undang-Undang Nomor 20 Tahun 2003 tentang Sistem Pendidikan Nasional

Wibowo, A. M. 2019. Kesalehan Ritual Dan Kesalehan Sosial Siswa Muslim SMA Di Eks Karesidenan Surakarta. Jurnal Smart, Vol. 5 No. 1. Halaman 29-43. 


\section{BIODATA PENULIS BUNGA RAMPAI "PENDIDIKAN AGAMA ISLAM DI SMP ISLAM TERPADU"}

Wahab. Lahir di Semarang, 13 Oktober 1958. Jabatan yang disandangnya saat ini adalah Peneliti Ahli Utama pada Balai Litbang Agama Semarang. Studi S1 diselesaikannya pada IAIN Walisongo Semarang, S2 di Universitas Negeri Semarang, dan saat ini sedang menempuh program Doktor di Universitas Negeri Semarang. Diantara karya-karyanya adalah "Pengembangan Perangkat Pembelajaran PKn Berbasis Karakter dengan Model Pembelajaran Kooperatif pada Madrasah Tsanawiyah" diterbitkan oleh CV. Pustaka Rizki Putra Semarang; "Internalisasi Nilainilai Karakter Bangsa melalui Pendidikan Agama Islam (PAI) pada Peserta Didik" diterbitkan oleh CV. Pustaka Rizki Putra Semarang; "Pergeseran Pondok Pesantren Salafiyah" diterbitkan oleh CV. Pustaka Rizki Putra; "Model Manajemen Pendidikan pada SMP IT Nurul Islam Tengaran Kabupaten Semarang" terbit pada Jurnal SMART Vol. 04 No. 01 Tahun 2018; "Pendidikan Agama Sekolah Luar Biasa pada SDLB-C Kertha Wiweka Kota Denpasar" terbit pada Jurnal Al-Qalam Vol. 23 No. 2 Tahun 2017.

Umi Muzayanah. Lahir di Banyumas tanggal 4 Januari 1978. Jabatan yang melekat padanya saat ini adalah Peneliti Muda pada Balai Litbang Agama Semarang. Studi S1 ia tempuh di Universitas Diponegoro Semarang dan S2 di Universitas Negeri Semarang. Karya yang pernah diterbitkan antara lain: "The Map of SMA/SMK Islamic Education Teachers' Competencies in Central Java” yang diterbitkan oleh Analisa: Journal of Social Science and Religion 


\section{Pendidikan Agama Islam di SMP Terpadu}

Volume 3 Nomor 02 Tahun 2018 (tulisan kolaboratif); "Trend Beragama Remaja Era Milenial: Analisis Perilaku Siswa SMA di Jawa Tengah" terbit pada Jurnal Fikrah Vol. 6 No. 2 Tahun 2018; "Fungsi Komunikasi dalam Trannsmisi Nilai-nilai Keagamaan pada Organisasi Kerohanian Islam (Rohis) di SMA N 1 Purworejo" terbit pada Jurnal Komunika Vol. 12 No. 1 Tahun 2018; "The Role of The Islamic Education Subject and Local Tradition in Strengthening Nationalism of The Border" terbit pada ANALISA Journal of Social Science and Religion, Vol. 2 No. 1 July 2017; "Kekerasan dalam Rumah Tangga dan Peran Lembaga Agama di Banyumas Jawa Tengah" terbit pada Jurnal SMaRT Vol. 02 No. 02 Desember 2016; "Kualitas Kinerja Pengawas Madrasah dalam Perspektif Guru dan Kepala Madrasah" terbit pada Jurnal Al-Qalam Vol. 22 No. 02 December 2016; "Penyelenggaraan Pendidikan Inklusif Pada Madrasah Ibtidaiah (MI) Keji Ungaran Jawa Tengah" terbit pada Jurnal Penamas Vol. 29 No. 02 September 2016. Selain artikel terbit pada jurnal, beberapa karya ilmiah lainnya terbit dalam prosiding, bunga rampai, dan monograf.

Siti Muawanah. Lahir di Grobogan, 5 Januari 1980. Pendidikan S1 ditempuh di IAIN (sekarang UIN) Walisongo Semarang, sedangkan S2 diselesaikan di UIN Syarif Hidayatullah Jakarta. Saat ini ia menjadi peneliti di Balai Penelitian dan Pengembangan Agama Semarang. Di antara pikiran yang telah dituangkan dalam bentuk tulisan adalah "Meaning Revealed: Grebeg Besar in Demak Central Java" terbit di Studia Islamika PPIM UIN Syarif Hidayatullah Jakarta Volume 13 Nomor 3 Tahun 2006; "Budaya Damai di Pesantren: Studi terhadap Al-Islam Gumuk" terbit di Jurnal Harmoni Puslitbang Kehidupan Kementerian Agama RI 


\section{Biodata Penulis}

Volume 12 Nomor 2 Tahun 2013; "Menggali Multikulturalisme di Sekolah (Studi terhadap SMA Katolik Soverdi Badung) dalam Mulyani Mudis Taruna (Ed.) Pendidikan Multikultural di Pulau Dewata.Yogyakarta: Arti Bumi Intaran, 2015; "Kejawen Spiritualism: The Actualization Of Moral Values in Paguyuban Suci Hati Kasampurnan in Cilacap, Central Java", terbit di Jurnal El Harakah: Jurnal Budaya Islam UIN Maulana Malik IbrahimVolume 19 Nomor 2 Tahun 2017; dan "Pemikiran Pendidikan K. H. Ali Maksum Krapyak Yogyakarta", terbit di Edukasi: Jurnal Penelitian Pendidikan Agama dan Keagamaan Puslitbang Pendidikan Agama dan Keagamaan Kementerian Agama RI Volume 16 No. 1 Tahun 2018. Dua tulisan yang terakhir adalah hasil kerja sama dengan Mustholehudin. Tulisan kolaboratif lain juga dapat ditemukan dalam artikel "The Map of SMA/SMK Islamic Education Teachers' Competencies in Central Java" yang diterbitkan oleh Analisa: Journal of Social Science and Religion Volume 3 Nomor 02 Tahun 2018. Beberapa tulisannya juga dapat ditemukan dalam beberapa prosiding dan bunga rampai.

A.M. Wibowo. Lahir di Lampung Tengah pada tanggal 25 Desember 1977. Jabatannya sekarang adalah Peneliti Madya pada Balai Litbang Agama Semarang. Pendidikan S1 dan S2 ia tempuh di IAIN Walisongo Semarang. Lima judul karya ilmiah terakhirnya diantaranya adalah "Multikulturalisme Peserta Didik Muslim Di Yogyakarta", terbit pada Jurnal Edukasi: Jurnal Penelitian Agama dan Keagamaan Volume 16 No 1 2018; "Political View and orientation of the Rohis members Toward The Form of the State", terbit pada Analisa Journal of Social Science And Religion Vo 2 No 2 Tahun 2017; "Kurikulum Pendidikan Agama Islam Berbasis 


\section{Pendidikan Agama Islam di SMP Terpadu}

Manuskrip Keagamaan (Analisis Heremeunetik Subyektif terhadap Serat Panitiboyo)", terbit dalam Jurnal Al Qalam Volume 23 No 2 tahun 2016; "Madrasah Diniyah Di Tengah Kampung PSK", terbit Jurnal Edukasia Islamika Volume 1 No. 1 Tahun 2016; "Gerakan Majelis tafsir Al Quran (MTA) dalam Konstelasi Kebangsaan Melalui Lembaga Pendidikan" dalam Bunga Rampai Radikalisme dan Kebangsaan Perspektif Pendidikan, diterbitkan CV. Arti Bumi Intaran Yogyakarta Tahun 2016.

Nugroho Eko Atmanto. Lahir di Kulon Progo tanggal 12 Okober 1973. Jabatan saat ini adalah Peneliti Muda pada Balai Litbang Agama Semarang. Studi S1 ditempuh di Universitas Gadjah Mada Yogyakarta dan S2 di IAIN Walisongo Semarang. Karya yang pernah diterbitkan antara lain: "Relevansi Konsep fajar dan Senja dalam Kitab Al Qanun Al Mas'udi bagi Penetapan Waktu Salat Isya' dan Subuh" terbit dalam Jurnal Analisa Vol. 19 No. 01 Juni 2012; "Pendidikan Damai Melalui Pendidikan Agama pada Sekolah Menengah Atas di Daerah Pasca Konflik: Studi di SMA St. Fransiskus Asisi Bengkayang dan SMA Shalom Bengkayang” terbit pada Jurnal SMART Vol. 3 Nomor 2 Desember 2017; "Evaluasi Pelaksanaan Kurikulum 2013 Mata Pelajaran Pendidikan Agama Islam di SMAN 1 Kudus" terbit pada Prosiding Bidang Pendidikan Agama dan Keagamaan Vo. 3 No. 1 Tahun 2016; "Transmisi Ideologi dan Pemikiran Menuju Cita-Cita Syariah dan Khilafah (Studi Kasus Hizbut Tahrir Indonesia DPD Kota Malang)" terbit dalam Bunga Rampai Radikalisme dan Kebangsaan Kelompok Keagamaan (Perspektif Pendidikan) Tahun 2016; "Implementasi Matlak Wilayatul Hukmi dalam Penentuan Awal Bulan Kamariah (Perspektif Nahdlatul Ulama dan Muhammadiyah)" terbit dalam jurnal Elfalaky Vol. 1 No. 1 Tahun 2017. 


\section{Biodata Penulis}

Ahmad Muntakhib. Lahir di Demak tanggal 12 Juli 1978. Jabatan yang disandang saat ini adalah Peneliti Pertama pada Balai Penelitian dan Pengembangan Agama Semarang. Ia menyelesaikan Pendidikan S1 di Pendidikan Bahasa Arab Fakultas Tarbiyah IAIN Walisongo Semarang dan S2 di Pascasarjana UIN Walisongo Semarang. Saat ini, ia sedang menempuh pendidikan program doktoral pada institusi yang sama. Karya yang pernah diterbitkan berjudul Model manajemen Madrasah Ibtidaiyyah Yusuf Abdus Sattar Lombok barat dalam bunga rampai Tiga Pilar manajemen menuju Madarasah Ideal, Urgensi pendidikan Karakter dalam Kitab al-Arbain al-nawawiyyah dalam meningkatkan kualitas Pendidikan di Indonesia, Kesiapan Madrasah Aliyah dalam menghadapi akreditasi di Jawa tengah, dan Pendidikan agama pada Pendidikan Anak Usia Dini.

Dandung Budi Yuwono. Lahir di Pekalongan tanggal 14 November 1961. Jabatan yang melekat padanya saat ini adalah Peneliti Ahli Madya pada LPPM UIN Sunan Kalijaga. Studi S1 ia tempuh di Fakultas Ekonomi UNS, dan S2 di Antropologi Budaya FIB UGM. Karya yang pernah diterbitkan antara lain: "Budaya Seks di Balik Jeruji" penerbit Kurnia Kalam Semesta (2018); "Konstruksi Sosial Atas Warisan Budaya Sunan Kudus" terbit pada Jurnal SMaRT Volume 03 Nomor 1, Juni 2017; "Kontroversi Pemikiran Teks Keagamaan Kiai Abdul Mu'thi, Pondok Pesantren AnNajah, Magelang" terbit pada Jurnal Panangkaran Nomor 2, JuliDesember 2017; "Memaknai Tradisi Istighosah Pasca Perusakan Makam Ndoro Purbo di Yogyakarta" terbit pada Analisa Journal of Social Science and Religion Volume 22 Nomor 02 Desember 2015; "Reproduksi Multikulturalisme di Tengah Pluralitas Masyarakat 


\section{Pendidikan Agama Islam di SMP Terpadu}

Batak" terbit pada Harmoni Jurnal Multikultural \& Multireligius Vol. 17 No. 2 Juli - Desember 2018.

Muh. Isnanto. Lahir di Boyolali pada tanggal 4 Juli 1967 adalah Peneliti Madya pada Pusat Penelitian dan Penerbitan LP2M UIN Sunan Kalijaga Yogyakarta. Gelar sarjana (S1) didapat dari Fakultas Ushuluddin IAIN Sunan Kalijaga Yogyakarta (1992). Gelar Magister (S2) dari Fakultas Ilmu Sosial dan Politik (FISIPOL) Program Studi Sosiologi UGM Yogyakarta (2004). Aktivitas lainnya di UIN Sunan Kalijaga adalah sebagai Dewan Penyunting "Musawa" Jurnal Studi Gender dan Islam (2015-sekarang), Redaktur Pelaksana Jurnal "Panangkaran" LPPM UIN Sunan Kalijaga (2017-sekarang), Pengelola PPGHA UIN Sunan Kalijaga (2015- sekarang), Kalijaga Institute for Justice (KIJ) UIN Sunan Kalijaga (2014-sekarang). Artikel yang pernah diterbitkan diantaranya adalah "Pemetaan Tema Penelitian pada Lembaga UIN Sunan Kalijaga Yogyakarta 1991-2012", terbita pada Jurnal "Smart" Volume 03 No. 1, Juni 2017; "Indeks Keterbacaan Buku Aqidah Akhlak Kelas XI di Madrasah Aliyah Kabupaten Bantul Yogyakarta", terbit pada Jurnal "Panangkaran" Vol. 1, No. 1, Januari-Juni 2017; "Gagasan dan Pemikiran Muhammadiyah tentang Kaderisasi Ulama (Studi Kasus tentang Ulama di Muhammadiyah)", diterbitkan oleh Jurnal Aplikasia Volume 17, No. 2. Juli-Desember 2017; "Hakim Perempuan Sebagai Keniscayaan Dalam Penegakkan HAM”, Book Review di Jurnal Musawa Pusat Studi Wanita UIN Sunan Kalijaga Vol.14,No.2, Juli 2015; "Harmonisasi Kurikulum: Literatur Klasik Dan Modern" (Studi tentang Pergeseran Literatur Di Pesantern Nurul Umah Yogyakarta) dalam Proseding, ISSN 2354-662X. Kemudian karya dalam bentuk buku diantaranya adalah "Jawara: 


\section{Biodata Penulis}

Premodialisme dan Realitas Kekinian", Yogyakarta, PT Kalam Kurnia Semesta, 2018, Buku "Modul Mediasi Sengketa Keluarga", Yogyakarta, PSW UIN Suka Tahun 2013. ISBN No. 978-602-150825-1, "Menuju Hukum Keluarga Progresif, Responsif Gender, dan Akomodatif Hak Anak", Yogyakarta: Suka Press-PSW UIN SukaThe Asia Foundation, Tahun 2013. ISBN 978-602-1326-01-5

Aji Sofanudin. Lahir di Tegal, 17 Desember 1978. Saat ini sebagai Senior Researcher pada Balai Penelitian dan Pengembangan Agama Semarang. Program S1 Fakultas Tarbiyah IAIN Walisongo Jurusan PAI lulus Tahun 2002. Program S2 Magister Studi Islam UII Yogyakarta konsentrasi Islamic Research lulus Tahun 2009. Lulusan terbaik Program S3 Manajemen Kependidikan UNNES tahun 2016 dengan IPK 4,0. Disertasinya berjudul "Model Inovasi Pendidikan Berorientasi Mutu pada Madrasah Ibtidayah (Studi pada Madrasah Partnership, Madrasah Berbasis Pesantren, dan Madrasah Model)". Beberapa tulisan populernya menghiasi media massa: Suara Merdeka dan Tribun Jateng. Berikut ini Karya Tulis Ilmiah (KTI) Aji Sofanudin yang terbit di Jurnal pada Tahun 2019, yaitu: "Kebijakan Kementerian Agama dalam Pelayanan Pendidikan Agama Kelompok Minoritas" terbit pada Jurnal PENAMAS Balai Litbang Agama Jakarta, Volume 32, Nomor 1, Januari - Juni 2019; "Best Practice Implementasi Kurikulum pada Sekolah Alam Insan Mulia (SAIM) Surabaya", diterbitkan oleh Jurnal SMART Balai Litbang Agama Semarang, Volume V, Nomor 1, Januari Juni 2019; "Survey Akhlak Siswa SMA Negeri di Provinsi Jawa Tengah", terbit pada Jurnal AL-QALAM, Balai Litbang Agama Makassar, Volume 25, Nomor 1 Januari - Juni 2019; "Curriculum Typology of Islamic Religion Education in Integrated Islamic School 


\section{Pendidikan Agama Islam di SMP Terpadu}

(SIT)", pada Jurnal EDUKASI Puslitbang Pendidikan Agama dan Keagamaan Badan Litbang dan Diklat Kemenag RI, Volume 17, Nomor 1 Januari - Juni 2019.

Mukhtaruddin. Lahir di Banyumas tanggal 6 Oktober 1954. Jabatan yang disandangnya pada saat menulis artikel ini adalah Peneliti Madya pada Balai Litbang Agama Semarang. Pendidikan S1 diselesaikan di IAIN Walisongo Semarang. Beberapa karya ilmiah yang sudah diterbitkan diantaranya adalah "Kerukunan Hidup Umat Beragama di Bali"; "Standarisasi Penguasaan Kitab Kuning"; "Kesiapan Madrasah dalam Menghadapi Akreditasi"; "Pengembangan Model Pembelajaran Kooperatif Berbasis Religi Pada Madrasah Tsanawiyah"; "Implementasi Pendidikan Ma'had "Aly"; dan "Pendidikan Kesehatan Reproduksi di SMA". Karyakarya tersebut terbit dalam bentuk prosiding dan bunga rampai.

Zakiyah. Peneliti madya pada Balai Litbang Agama Semarang. Gelar Magisternya diperoleh dari dua perguruan tinggi, yaitu dari Universitas Islam Negeri Sunan Kalijaga, Yogyakarta (2006) dan the University of Queensland Australia (2014). Beberapa karya tulis ilmiah yang telah diterbitkan, antara lain: "Pendidikan Kepercayaan terhadap Tuhan Yang Maha Esa: Pemenuhan Hak Siswa Penghayat di Sekolah (Jurnal Penamas, 2018); "Manuscripts in Sumenep Madura: the Legacy of Pesantren and its Ulama" (Jurnal Heritage of Nusantara, 2017); "Indeks Kualitas Pelayanan Pernikahan oleh KUA di Kabupaten Kebumen Jawa Tengah” (Jurnal Al Qalam, 2017); “Cendekiawan Muslim dan Wacana Konflik Etnis di Kalimantan Barat" (Jurnal Panangkaran, 2017); "Mamacan di Desa Bayan Lombok Utara: Menjaga Tradisi Lokal dan Diseminasi 


\section{Biodata Penulis}

Ajaran Islam" dalam buku: "Islam Kontemporer di Indonesia dan Australia" (diterbitkan oleh Australian Embassy Jakarta, Australia Global Alumni, PPIM UIN Jakarta, dan UIN FISIP. 2017); "Dewi Maleka; the Javanese Islam Manuscript" (Indonesian Journal of Islam and Muslim Society, 2016). "The Chronicle of Terrorism and Islamic Militancy in Indonesia" (Analisa Journal of Social Science and Religion, 2016); "Female Leadership in Indonesian Pesantren (Jurnal Penamas, 2016). 


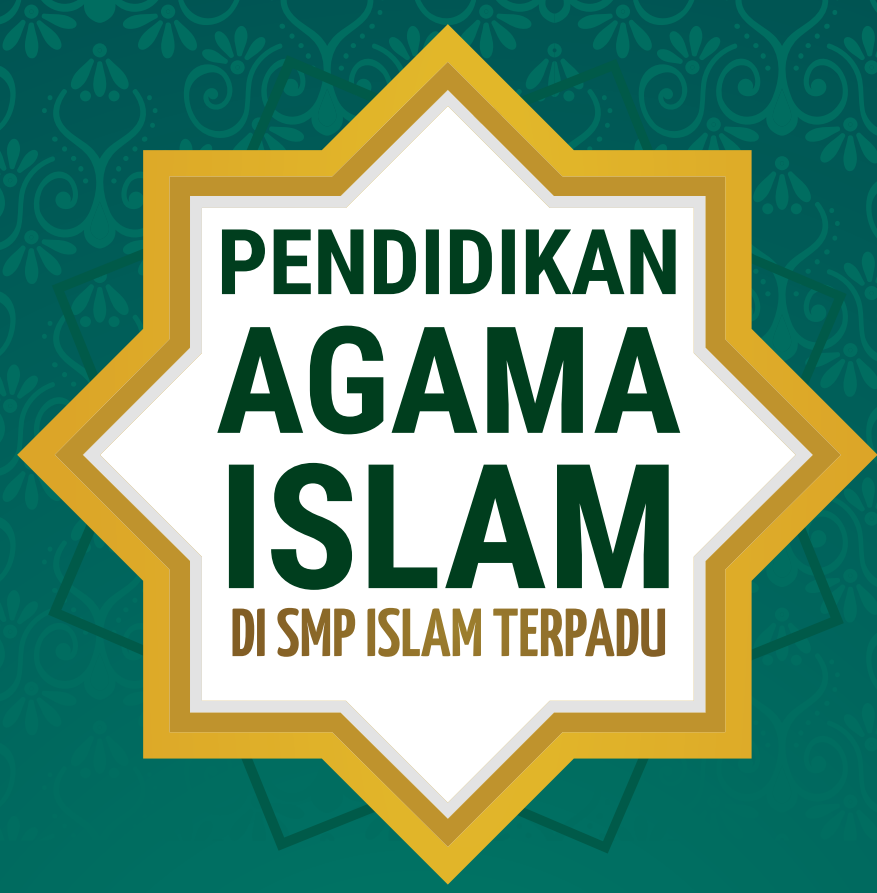

Buku Pendidikan Agama Islam di SMP Islam Terpadu ini berisi kumpulan artikel yang berangkat dari penelitian "Implementasi Pendidikan Agama Islam (PAI) di SMPIT di Jawa Tengah, Jawa Timur, dan D.I. Yogyakarta". Deskripsi tentang pelaksanaan PAI di sekolah Islam Terpadu tergambarkan dalam buku ini, yang dibatasi pada kajian PAI di jenjang SMPIT. Buku ini terdiri dari sebelas tulisan, yang ditulis oleh peneliti Balai Litbang Agama Semarang.

Buku ini memberikan informasi bagaimana praktik pelaksanaan PAI di SMPIT yang memiliki ciri khas pada pengembangan kurikulum terpadu. Kajian tersebut penting dalam menambah wawasan terkait warna dan inovasi pendidikan, khususnya yang berkaitan dengan Pendidikan Agama Islam.
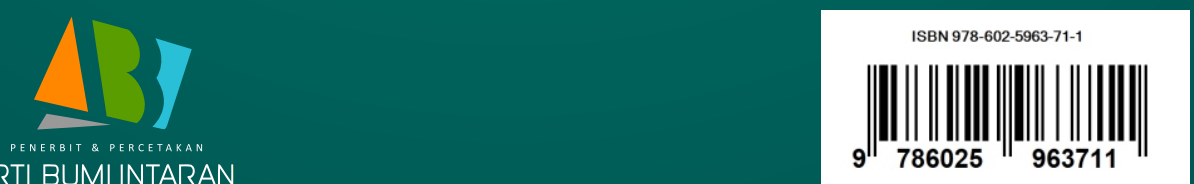